\title{
The Potential Role of Flavonoids in Ameliorating Diabetic Cardiomyopathy via Alleviation of Cardiac Oxidative Stress, Inflammation and Apoptosis
}

\author{
Fatin Farhana Jubaidi $\left.{ }^{1}{ }^{(}\right)$, Satirah Zainalabidin ${ }^{2}$, Izatus Shima Taib ${ }^{1}{ }^{\oplus}$, Zariyantey Abd Hamid ${ }^{1}$ \\ and Siti Balkis Budin ${ }^{1, *}$ \\ 1 Center for Diagnostic, Therapeutic and Investigative Studies, Faculty of Health Sciences, \\ Universiti Kebangsaan Malaysia, Kuala Lumpur 50300, Malaysia; fatinfarhanajubaidi@gmail.com (F.F.J.); \\ izatusshima@ukm.edu.my (I.S.T.); zyantey@ukm.edu.my (Z.A.H.) \\ 2 Center for Toxicology and Health Risk Studies, Faculty of Health Sciences, Universiti Kebangsaan Malaysia, \\ Kuala Lumpur 50300, Malaysia; satirah@ukm.edu.my \\ * Correspondence: balkis@ukm.edu.my; Tel.: +603-9289-7645
}

check for updates

Citation: Jubaidi, F.F.; Zainalabidin, S.; Taib, I.S.; Hamid, Z.A.; Budin, S.B. The Potential Role of Flavonoids in Ameliorating Diabetic

Cardiomyopathy via Alleviation of Cardiac Oxidative Stress, Inflammation and Apoptosis. Int. J. Mol. Sci. 2021, 22, 5094. https:// doi.org/10.3390/ijms22105094

Academic Editor: Francesca Truzzi

Received: 10 March 2021

Accepted: 30 April 2021

Published: 12 May 2021

Publisher's Note: MDPI stays neutral with regard to jurisdictional claims in published maps and institutional affiliations.

Copyright: (c) 2021 by the authors. Licensee MDPI, Basel, Switzerland. This article is an open access article distributed under the terms and conditions of the Creative Commons Attribution (CC BY) license (https:/ / creativecommons.org/licenses/by/ $4.0 /)$.

\begin{abstract}
Diabetic cardiomyopathy is one of the major mortality risk factors among diabetic patients worldwide. It has been established that most of the cardiac structural and functional alterations in the diabetic cardiomyopathy condition resulted from the hyperglycemia-induced persistent oxidative stress in the heart, resulting in the maladaptive responses of inflammation and apoptosis. Flavonoids, the most abundant phytochemical in plants, have been reported to exhibit diverse therapeutic potential in medicine and other biological activities. Flavonoids have been widely studied for their effects in protecting the heart against diabetes-induced cardiomyopathy. The potential of flavonoids in alleviating diabetic cardiomyopathy is mainly related with their remedial actions as anti-hyperglycemic, antioxidant, anti-inflammatory, and anti-apoptotic agents. In this review, we summarize the latest findings of flavonoid treatments on diabetic cardiomyopathy as well as elucidating the mechanisms involved.
\end{abstract}

Keywords: diastolic dysfunction; flavone; flavonol; flavanol; isoflavone; systolic dysfunction

\section{Introduction}

The incidence of diabetes mellitus and its related complications have become a threat to global health and is a major factor to high morbidity and mortality. Leading up to 2045, it is expected that the global population of diabetic patients will rise to up to 700 million [1]. Cardiovascular diseases generally are the main factors that contribute to the high morbidity among diabetic patients [2]. A study on cardiovascular-related hospitalizations has revealed that more than $35 \%$ of all hospitalization were patients with diabetes mellitus and that more than $25 \%$ are due to diabetic-related cardiovascular complications [3].

Diabetic cardiomyopathy (DCM) can be defined as abnormality in the myocardial structure and function in the absence of other cardiovascular factors, such as artery coronary diseases, hypertension, congenital and valvular heart diseases [4]. DCM is characterized by left ventricular wall hypertrophy with regressed diastolic function at its early development before this condition worsens as extensive cardiac fibrosis and hypertrophy develops, causing further impairment of diastolic dysfunction. The advanced stage of DCM is characterized with the appearance of systolic dysfunction along with the aforementioned cardiac structural and functional disturbances [5]. In a clinical scenario, DCM development could only be detected when the signs and symptoms of regressed cardiac functions appeared, as DCM has reached the late stage (significant diastolic and systolic dysfunction) and heart failure events have already been initiated [6].

To date, there is no specific treatment to treat and limit diabetic cardiomyopathy progression. Diabetic patients are only given therapeutic drugs to manage the hyperglycemic 
condition (via management with glucose-lowering agents and insulin therapy) and cardiovascular complications (via the administration of beta blockers and angiotensin-converting enzyme inhibitors) $[7,8]$. However, these medications have specific toxic side effects, and long-term use of insulin therapy causes decreased insulin receptor sensitivity, resulting in insulin resistance and eventually leading to worsening of control conditions [9]. Currently, several new targeted drugs have been developed and have entered the market, such as DPP-4 inhibitors, GLP-1 analogs, and SGLT-2 inhibitors [10]. However, the high cost of these drugs leads to difficulties in meeting the high demand from patients with diabetes and limits the clinical application of these drugs. Therefore, research exploring the alternative treatment to treat and limit the progression of DCM is very much needed.

Flavonoids are the most common occurring plant phenolic compounds [11]. On average, flavonoids are consumed daily from diet at approximately $400 \mathrm{mg} / \mathrm{kg}$ aglycone equivalent (AE). They have been reported to exhibit diverse therapeutic potential in medicine and other biological activities [12-14]. The potential of flavonoids in alleviating diabetic cardiomyopathy or other cardiovascular complications derived from diabetes have been commonly related with their remedial actions as anti-hyperglycemic [15], antihyperlipidemic [16], antioxidant [17], anti-inflammatory [18], and anti-apoptotic [19] agents. Considering the promising potential of flavonoids in combating diabetic cardiomyopathy development, we aimed to review the potential mechanisms that flavonoids and their subclasses target in order to exert their cardioprotective potential.

The literature search was completed using the PubMed database, and relevant keywords (flavonoid; diabetic cardiomyopathy; in vitro; in vivo; inflammation; apoptosis; oxidative stress; fibrosis; hypertrophy; cardiac dysfunction) were used. Based on the search findings, we summarized the articles and integrated the literature search accordingly.

\section{Diabetic Cardiomyopathy: Understanding the Cardiac Oxidative Stress, Inflammation, and Apoptosis-Related Pathophysiology and Pathogenesis}

Rubler et al. [20] gave the earliest clinical description of diabetic cardiomyopathy; they reported post-mortem findings from four diabetic patients whose death were caused by heart failure. In these patients, they noticed that the patients lacked common heart failure risk factors, which are hypertension, myocardial ischemia or any other valvular and congenital heart diseases. Instead, the cardiac failures were established to be caused by the pre-existing diabetes mellitus in the patients. The European Society of Cardiology (ESC) suggested that the diabetic cardiomyopathy condition is related to the cardiac dysfunction observed in diabetic patients in the absence of other cardiac diseases, including coronary artery diseases, uncontrolled hypertension, and congenital and valvular heart diseases [21].

As previously mentioned, Paolillo [5] suggested the two stages of diabetic cardiomyopathy; the early stage featuring left ventricular hypertrophy and diastolic dysfunction as the diabetes mellitus progresses; diabetic cardiomyopathy advanced at a late stage with prominent diastolic dysfunction, extensive myocardial fibrosis, systolic dysfunction, and eventually left ventricular dilation (Table 1 and Figure 1). Initially, the asymptomatic left ventricular hypertrophy seen in the early development of DCM resulted from the adaptive response to increased hemodynamic pressure [22], diminished viable cardiomyocyte population [23] and neurohormonal activation [24]. Reduction in cardiomyocyte population is caused by extensive cardiomyocyte death resulting from oxidative damage and apoptosis is induced by chronic hyperglycemia. Due to this, viable cardiomyocytes have to bear the burden to generate enough force in order to pump blood from and into the heart, subsequently causing the cells to enlarge, known as the pathological hypertrophy $[25,26]$. 
Table 1. Clinical stages of diabetic cardiomyopathy according to Paolillo et al. [5].

\begin{tabular}{cc}
\hline Diabetic Cardiomyopathy Stage & Clinical Findings \\
\hline Early stage & $\begin{array}{c}\text { Left ventricular hypertrophy; Diastolic dysfunction; } \\
\text { Increase in left atrial filling pressure }\end{array}$ \\
\hline Advanced stage & $\begin{array}{c}\text { Aggravated diastolic dysfunction; Extensive } \\
\text { myocardial fibrosis }\end{array}$ \\
& Systolic dysfunction; Left ventricular dilatation \\
\hline
\end{tabular}

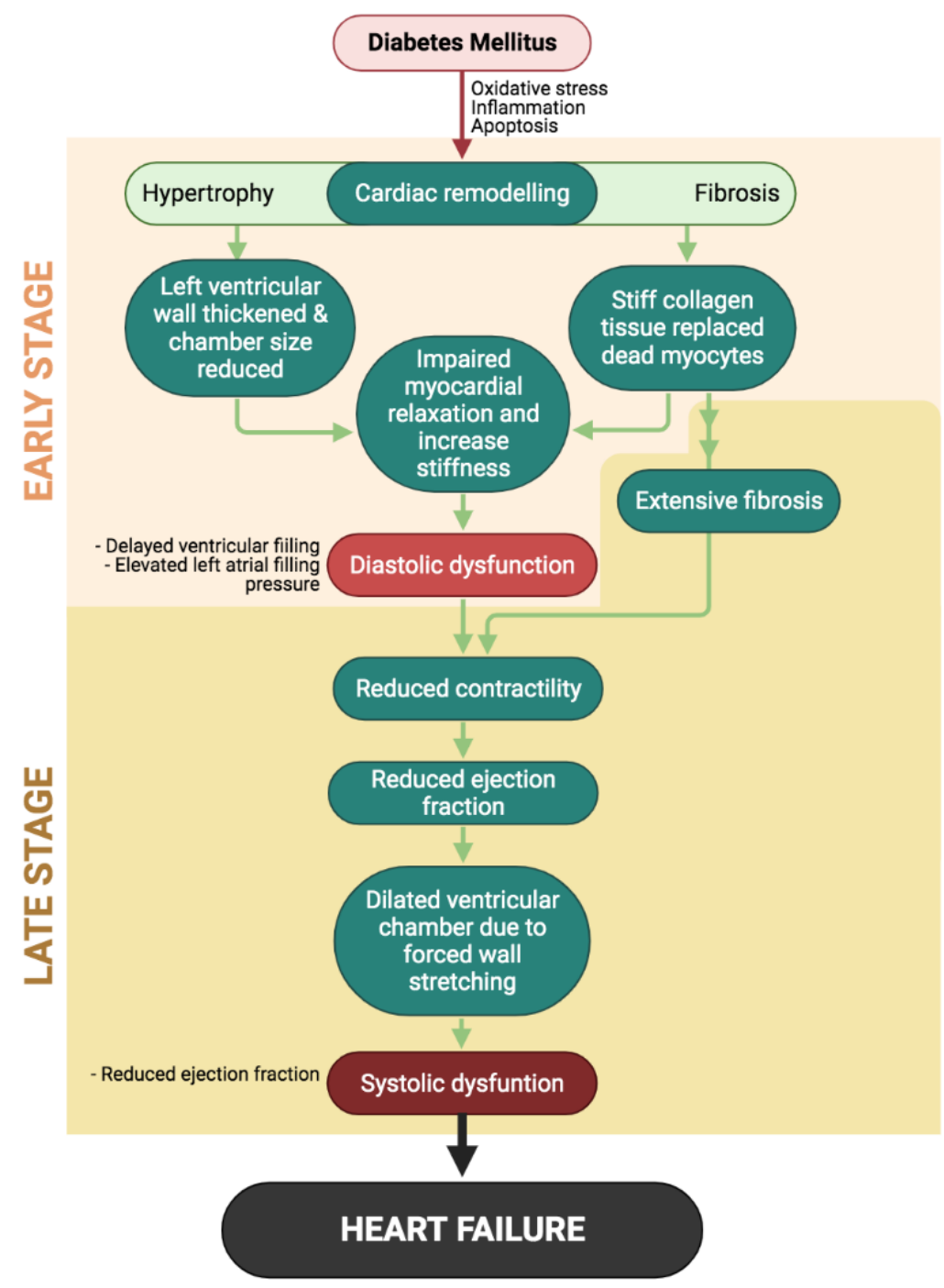

Figure 1. Events in the development and progression of diabetic cardiomyopathy (DCM) initiated by diabetes-induced uncontrolled cardiac remodeling. The early stage of DCM mainly characterized by diastolic dysfunction will progress to late stage as systolic dysfunction appears, eventually leading to heart failure.

Aside from cardiac hypertrophy, myocardial fibrosis is one of the main features defining the structural changes in DCM. Fibrosis occurs along with hypertrophy as a cardiac remodeling process to preserve the heart structure. The deposition of fibrotic tissue, including collagen I and collagen III, in the extracellular matrix (ECM) space is to replace the dead cardiomyocytes, and the stiff nature of collagen tissue causes the heart to lose its contractility and flexibility [27]. Gliozzi et al. [28] explained that the downregulation of matrix metallaprotenaise-2 (MMP-2) during the progression of DCM results in collagen deposition in the ECM, leading to the rigid myocardium. The downregulation of MMP-2 
was associated with the translocation of $\mathrm{N}$ terminal truncated MMP-2 from the cytosol into the mitochondria, leading to mitochondrial dysfunction that enhances cardiac dysfunction. Via synthesis and release of growth factors and cytokines, a hyperglycemia condition also promotes fibroblast proliferation and transdifferentiation of myofibroblasts as well as activating the transcription of extracellular matrix protein [29].

Hyperglycemia, a common trait shared in both Type 1 (insulin dependent) and Type 2 (non-insulin dependent) diabetes mellitus, resulting from impaired insulin signaling, is one of the major etiologies for cardiovascular complications in diabetic patients. Disorder of glycometabolism leads to the persistent hyperglycemia which induces reactive oxygen species (ROS) production in the myocardium via several pathways, including the generation of advanced glycation end products (AGE) as well as activation of polyol, hexosamine, and protein kinase $C$ pathways [30]. Accumulation of ROS further aggravates myocardial oxidative stress, exacerbating dysfunction of mitochondria, which leads to cardiomyocyte deaths and the subsequent cardiac remodeling (cardiac hypertrophy and fibrosis) to preserve the cardiac function and integrity. Uncontrolled and excessive cardiac remodeling further disturbs the ability of the heart to contract and relax efficiently, resulting in the development of diastolic and systolic dysfunctions along with the appearance of prominent cardiac structural changes, both of which are the diagnostic features of diabetic cardiomyopathy [5].

Cardiomyocyte death occurs via several pathways including lipotoxicity and production of AGE following high glucose level in the blood. AGE production induces inflammation, infiltration of immune cells, and apoptotic factors [31], as summarized in Figure 2. Replacement of dead cells with fibrosis is aggravated when protein kinase C (PKC) and its downstream cascades and proteins are activated by hyperglycemia. Chronic exposure to a high glucose environment is related to organ and tissue injury including micro- and macrovascular injury, neuropathy, and nephropathy. Hyperglycemia-induced oxidative stress activates several inflammatory and apoptotic pathways that are involved in the development of DCM [32]. Aside from lipid peroxidation and protein carbonylation in the cell membrane of cells, reactive oxygen species (ROS) that are excessively produced could also activate inflammatory and apoptotic signaling pathways in the heart [33]. Moreover, previous reports also mentioned the increased pro-inflammatory cytokines expression in the diabetic hearts of experimental rodent models [34,35]. Moreover, excessive superoxide production that overwhelms the cardiac natural antioxidant defense has been widely discussed to play a significant role in the development of DCM. Furthermore, they overtly trigger various pathways, which leads to the deterioration and alteration of cardiac function and structure; the superoxide itself was found to directly induce cardiomyocyte apoptosis aside from mitochondrial dysfunction [28].

Persistent hyperglycemia not only increases ROS production, but it can also result in the de novo production of diacylglycerol (DAG) via the glycolytic process of glucose [36]. DAG plays a role as an important cellular second messenger and is known to mediate the activation of the PKC signaling pathway. Aside from the DAG trigger, PKC pathways are also directly activated by accumulating ROS. Production of ROS is further enhanced by the activation of mitochondrial NADPH oxidase by PKC. Mediated by the activation of mitogen-activated protein kinases (MAPKs) pathways downstream of PKC signaling pathway, cardiomyocyte inflammation and apoptosis were further exacerbated [37]. While activation of extracellular regulated kinase (ERK) 1/2 pathway is suggested to promote cardiomyocyte survival via its anti-apoptotic effect [38], its activation also further enhances cardiomyocyte hypertrophy, making it a double-edged sword. Augmentation of cardiomyocyte hypertrophy via the activation of p38-MAPK and c-Jun N-terminal kinase (JNK) pathways dull the cell survival effect of ERK $1 / 2$ by increasing the Bax/Bcl-2 apoptotic ratio [39]. 


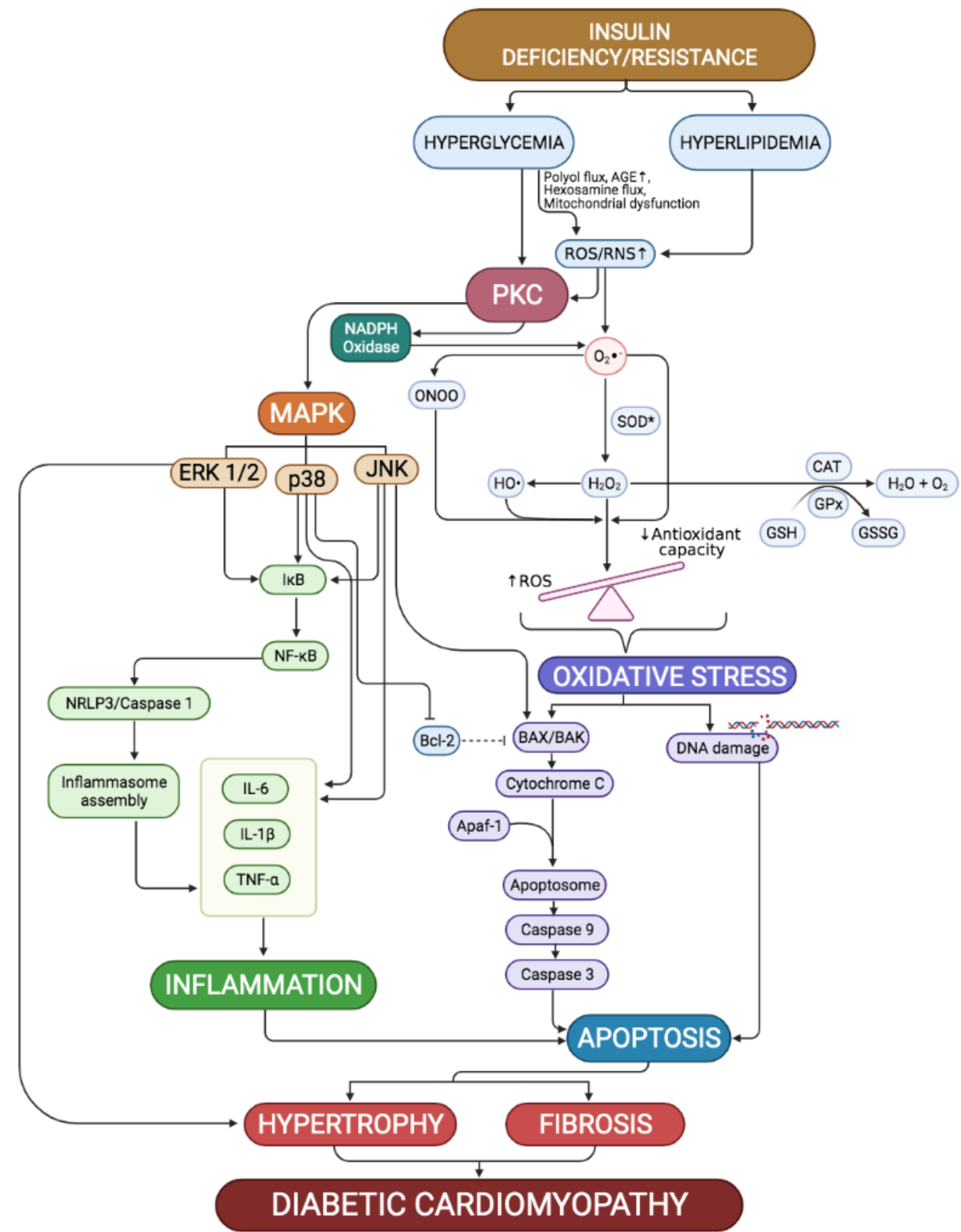

Figure 2. Summary of the mechanisms involved in the pathogenesis of diabetic cardiomyopathy. Hyperglycemia and hyperlipidemia resulting from insulin dysregulation induces excessive production of reactive oxygen and nitrogen species (ROS and RNS), generating oxidative stress in the cardiomyocytes. ROS also activates protein kinase C (PKC) pathways, which induces inflammation and cell apoptosis via mitogen-activated protein kinase (MAPK) pathways. Uncontrolled cardiomyocyte deaths lead to cardiac remodeling by cardiomyocyte hypertrophy and myocardial fibrosis as adaptive mechanisms to preserve the integrity of the heart. This structural alteration causes the heart to functionally regress as both diastolic and systolic dysfunction developed, conditions which define diabetic cardiomyopathy.

\subsection{Cardiac Oxidative Stress}

Oxidative stress is a well-established etiology for various pathologies, including diabetic cardiomyopathy. Oxidative stress results from the redox imbalance in the cell, whereby the endogenous antioxidant defense system is overwhelmed by the accumulation of ROS [40]. Accumulation of ROS and its persistent high level is enhanced by impaired endogenous antioxidant system, leading to diabetes-associated cell inflammatory and apoptotic response, thus contributing to the development and progression of 
DCM. Mitochondrial NADPH oxidase activation is a major source of cardiac ROS in diabetic conditions, boosted by diabetic-induced mitochondrial dysfunction and activation of PKC pathway [4]. In normal condition, endogenous superoxide dismutase (SOD) will catalyze the dismutation of superoxide radicals into hydrogen peroxide $\left(\mathrm{H}_{2} \mathrm{O}_{2}\right) . \mathrm{H}_{2} \mathrm{O}_{2}$ will then break down into a water and oxygen molecule by catalase and the indirect action of glutathione peroxidase [4]. Production of advanced glycation end products (AGE) by non-enzymatic glycosylation of protein and lipid could increase the production of ROS. AGE would bind to its receptor on cell surface, the receptor for AGE (RAGE), inducing inflammatory response and apoptosis of the cells [41].

Hyperglycemia-induced oxidative stress has been heavily implicated as the key role in the development and progression of cardiac dysfunction in diabetic patients. Via the elevation in NADPH oxidase activity, which results in the excessive production of ROS, cardiac function was compromised as this process promotes $\mathrm{Ca}^{2+}$ intake into the cardiomyocytes. Excessive ROS production was also found to induce cardiomyocyte apoptosis, mediated by overexpression of $18 \mathrm{kDa}$ translocator protein (TSPO) and voltage-dependent anion-selective channel 1 (VDAC1) that is involved in the formation of mitochondrial transition pores, resulting in mitochondrial dysfunction and cardiomyocyte apoptosis [27].

The activation of nuclear erythroid 2-related factor 2 (Nrf2) has been associated with a cardioprotective effect via the regulation of cellular antioxidant productions. Upregulation of Nrf2 has been shown to improve cardiac oxidative stress, making it an ideal target for cardiac adjuvant therapy, especially in preventing hyperglycemia-induced development of DCM, which is closely related to uncontrolled oxidative stress [42]. Normally, Nrf2 is bound to Kelch-like ECH-associated protein (Keap1) and stays in the cystosol. Upon activation, Keap1 dissociates from Nrf2, allowing it to translocate into the nucleus and bind to its promoter side. This results in the transcription of genes encoding for endogenous antioxidants (SOD, catalase, glutathione peroxidase) and phase II antioxidant enzymes (heme oxygenase-1, NADPH dehydrogenase and $\gamma$-glutamylcysteine synthtase), thus alleviating oxidative stress [43]. As oxidative stress brings about most cardiac complications in the diabetic condition, the Nrf2 pathway serves as one of the best targets in treating DCM.

\subsection{Cardiac Inflammation}

Cardiac inflammation has been reportedly responsible in DCM development [44]. Inflammation is considered as an adaptive response to restore cellular homeostasis when stress is being exerted on cells [34]. However, when the stress that is being exerted is persistent, such as in diabetes, it does not take long for this adaptive response to turn maladaptive and exert damaging effects instead. Studies showed that pro-inflammatory cytokines including tumor necrosis factor- $\alpha$ (TNF- $\alpha$ ), interleukin- $1 \beta$ (IL-1 $\beta$ ) and IL-6 all play a major role in the development of cardiomyocyte hypertrophy $[45,46]$. Persistent hyperglycemia was found to induce the expression of these cytokines in the heart by activating the MAPK pathways (JNK and p38-MAPK), causing cardiac damage, which further aggravates the infiltration and accumulation of leukocytes onto the affected site [47]. On top of that, it has been implicated that the downregulation of sirtuin-1 (SIRT-1) activity induced by persistent hyperglycemia condition and high insulin environment also plays a significant role in the development of diabetic cardiac inflammation [48].

Cardiac inflammation is also enhanced by increased lipid level in the blood, which in turn would activate toll-like receptor-4 (TLR-4) and aggravate cardiac inflammation via the NF-kB pathway [49]. Both hyperlipidemia and hyperglycemia enhance cardiac inflammation by activating the PKC/MAPK pathways. Degradation of IKB via both $p$ 38 and JNK pathways activates NF- $\mathrm{KB}$ [50]. Oxidative stress is also further exacerbated by persistent hyperglycemia and hyperlipidemia, in which PKC activation also plays a role by activating mitochondrial NADPH oxidase [51]. Inhibition of Nrf-2 by ERK $1 / 2$ exaggerates oxidative stress, which in turn activates NF- $\mathrm{KB}$ [52]. These evidence shows that via activating NF- $\mathrm{kB}$, which promotes the production of pro-inflammatory cytokines and causes hyperglycemia and hyperlipidemia, which are able to induce cardiac inflammation. 


\subsection{Cardiomyocyte Apoptosis}

Apoptosis, also known as programmed cell death, is the quickest form of cell death [53]. Cardiomyocyte apoptosis can occur when adaptive responses to return cardiac homeostasis and stressor-reducing attempts have all failed. Chen et al. [54] closely correlates persistent hyperglycemia with the eventual cardiomyocyte apoptosis. In other organs, such as skin and liver, apoptosis is an important process to maintain the organ and tissue homeostasis. However, in organs in which cells have very limited regeneration ability, cell death by apoptosis is rather damaging, as the tissue is unable to completely regenerate back to its original condition [54]. Extensive cardiomyocyte apoptosis results in the loss of contractile units of the heart. This results in substantial cardiac hypertrophy and fibrosis, consequently reducing the heart's ability to contract and relax as normal, which leads to the development of diastolic and systolic dysfunction, eventually leading to heart failure if left without intervention [5].

Both in vivo and clinical studies have proven that cardiac apoptosis plays a major role in the regressed function of the heart in diabetic conditions, mainly induced and derived from a high glucose level [55-57]. Caspases are a family of inactive proenzymes that play an important role in apoptosis. Caspases are being activated by other procaspases, depending on the specific activity. This results in a proteolytic cascade that promotes cell apoptosis, which results in permanent cell death [58]. Cell apoptosis occurs via two pathways, the extrinsic and intrinsic pathways, and both may occur concurrently. The extrinsic pathway is also known as the death receptor pathway, as it involves the binding of a stressor onto its receptor on the cell. Examples of cell death inducers are tumor necrosis factor $\alpha$ (TNF- $\alpha$ ) and Fas ligands. Their binding activates caspase 8 and caspase 9 , which in turn activate the executioner caspases (caspase 3, caspase 6, and caspase 7), resulting in the initiation of apoptosis [53]. The intrinsic pathway, also known as the mitochondrial apoptotic pathway, involves the dysfunction of mitochondria. By the intrinsic pathway, a pore is formed on the mitochondrial membrane by B-cell lymphoma (Bcl-2) protein family members, Bax and Bak, which extend across both inner and outer membranes of the mitochondria. This permits the mitochondrial cytochrome $\mathrm{c}$ to be released into the cystosolic compartments, in which interaction with apoptosis protease activating factor-1 (Apaf-1) then forms a complex known as apoptosome. Apoptosomes assist in the cleavage and activation of the downstream caspases, and eventually lead to cell death [54].

Increased apoptotic cell death in the heart of type 1 and type 2 diabetic patients and experimental animal models has been reported in previous study [59]. An experimental study revealed that there was a significant increase in caspase 3 cleavage, caspase $3 / 7$ activities and chromatin fragmentation and increased apoptosis in the heart of diabetic mice [60]. Increased activity of caspase 9, the mitochondrial pathway mediator, was observed in the hearts of diabetic patients [61]. Zhao et al. [62] demonstrated the disturbances in pro- and anti-apoptotic signaling proteins in diabetic myocardial cells. Wang et al. [63] demonstrated an increased rate of apoptosis in the hearts of diabetic mice through a dramatic increase in the $\mathrm{Bax} / \mathrm{Bcl}-2$ ratio and the caspase 3 and 9 expression.

\section{Flavonoid}

With at least 6000 compounds being identified, flavonoids are one of the major and largest group of plant secondary metabolites. They are widely found in fruits and vegetables. In general, flavonoid is structurally made up of two benzene rings (A and B), which are linked by a heterocyclic ring containing oxygen (C). As mentioned before, depending on the variant in the chemical structure, flavonoids are differentiated into six different classes [64]. The classes are (1) flavones, (2) flavonol, (3) flavanol, (4) flavanone, (5) isoflavone, and (6) anthocyanidin. As shown in Figure 3, the difference varies because of the connection between the $\mathrm{B}$ and $\mathrm{C}$ rings, the structure of $\mathrm{B}$ ring, and the hydroxylation and glycosylation patterns of the three main rings [65]. Most flavonoids exist in the form of glycosides or carbohydrate groups in plants and partly exist in free form. A majority of plants contain flavonoids, which play an essential role in plant growth, development, and 
flowering and even have antibacterial and disease prevention effects [66]. Flavonoid use in traditional medicine predates modern medicine, and their medicinal values are mainly because of their potent antioxidant properties. Zhang et al. [67] reported that puerarin, an isoflavone derived from Radix puerariae root, was used traditionally as anti-diabetic agents. As summarized in Table 2, flavonoids have been shown to exert protective effects against diabetic cardiomyopathy.

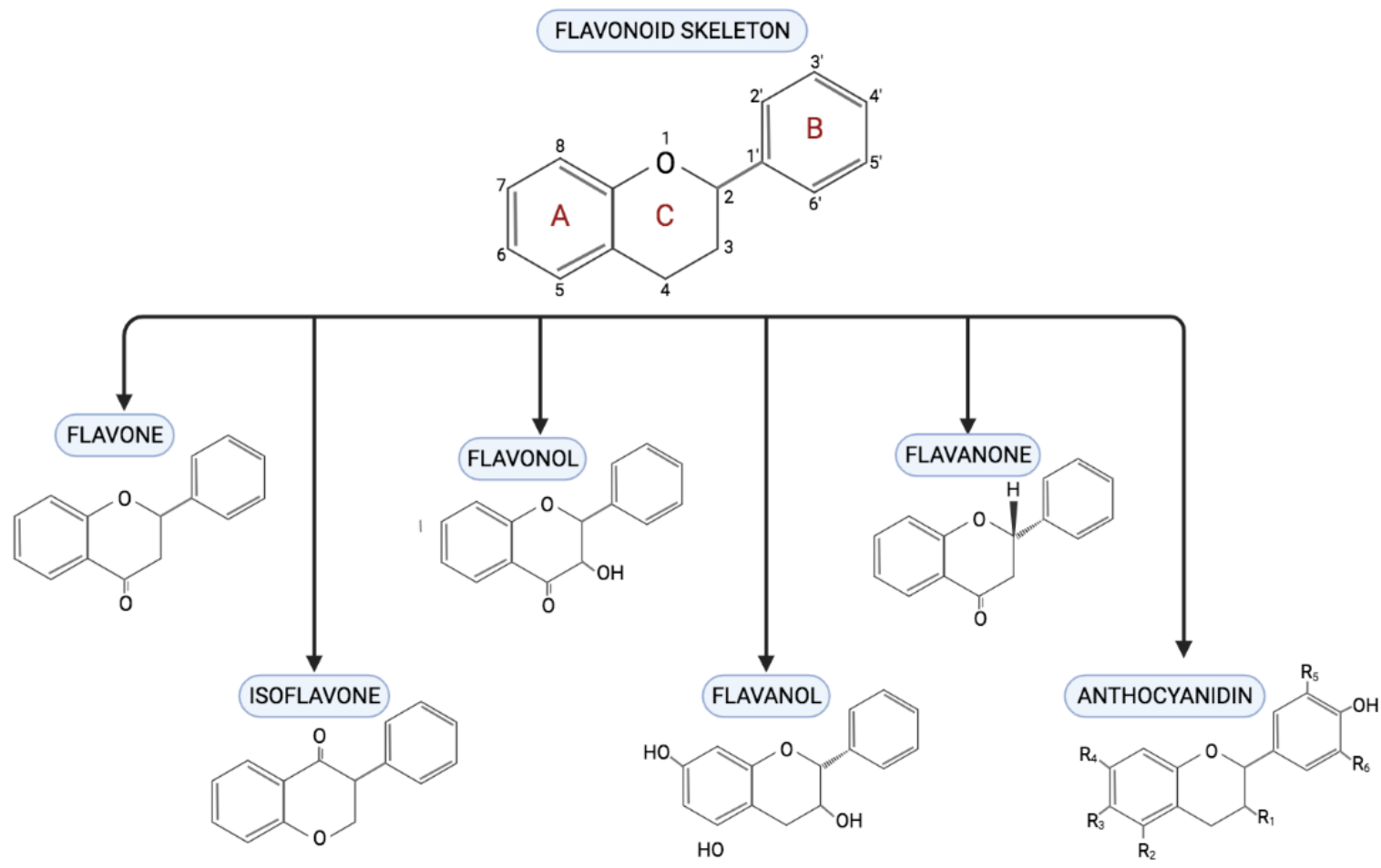

Figure 3. Chemical structures of different classes of flavonols. All flavanols classes share the same chemical bone, comprising two benzene rings (A and B) linked by a heterocyclic ring. Each flavonols are grouped into their classes based on the connection between the $\mathrm{B}$ and $\mathrm{C}$ rings as well as the hydoxylation and glycosylation patterns of the three main rings.

Table 2. Summary of cardioprotective effects exerted by different types and classes of flavonoids.

\begin{tabular}{|c|c|c|c|c|c|}
\hline Flavonoid Class & $\begin{array}{l}\text { Flavonoid } \\
\text { Subclass }\end{array}$ & Study Design & Dose & Results & Reference \\
\hline Anthocyanin & Anthocyanin & $\begin{array}{l}\text { In vivo; } \\
\text { T1DM rats }\end{array}$ & $250 \mathrm{mg} / \mathrm{kg} /$ day & $\begin{array}{l}\text { Improve cardiac dysfunction, significant } \\
\text { reduction in cardiac hypertrophy } \\
\text { and fibrosis. }\end{array}$ & Chen et al. 2016 [68] \\
\hline \multirow[b]{2}{*}{$\begin{array}{l}\text { Epigallocatechin- } \\
\text { 3-gallate }\end{array}$} & Flavanol & $\begin{array}{c}\text { In vivo; } \\
\text { Goto-Kakizaki rats }\end{array}$ & $100 \mathrm{mg} / \mathrm{kg} /$ day & Improved cardiac mitochondrial function. & Liu et al. 2014 [59] \\
\hline & Flavanol & In vivo; T1DM rats & $2 \mathrm{mg} / \mathrm{kg}$ & $\begin{array}{l}\text { Ameliorated diabetic phenotypes } \\
\text { prevented cardiac injury, improved cardiac } \\
\text { oxidative stress, and prevented } \\
\text { cardiomyocyte apoptosis. }\end{array}$ & Othman et al. 2017 [69] \\
\hline $\begin{array}{l}\text { Epicatechin-rich } \\
\text { (polyphenol) }\end{array}$ & Flavanol & In vivo; $\mathrm{T} 2 \mathrm{DM}$ rats & $100 \mathrm{mg} /$ day & $\begin{array}{l}\text { Improved cardiac mitochondrial function } \\
\text { and structure in diabetic rats. }\end{array}$ & Taub et al. 2011 [70] \\
\hline \multirow{2}{*}{ Luteolin } & Flavone & $\begin{array}{l}\text { In vivo \& in vitro; } \\
\text { H9C2 cells \& } \\
\text { T1DM mice }\end{array}$ & $5,10 \mu \mathrm{M} ; 20 \mathrm{mg} / \mathrm{kg}$ & $\begin{array}{l}\text { Significantly reduced cardiac inflammation } \\
\text { and oxidative stress via inhibition of the } \\
\text { NF- } k \text { B pathway as well as increasing } \\
\text { Nrf2 expression. }\end{array}$ & Li et al. 2016 [71] \\
\hline & Flavone & In vivo; T1DM rats & $100 \mathrm{mg} / \mathrm{kg} /$ day & $\begin{array}{l}\text { Significantly improved cardiac function } \\
\text { and mitochondrial function by increasing } \\
\text { cardiac antioxidants. }\end{array}$ & Xiao et al. 2019 [72] \\
\hline
\end{tabular}


Table 2. Cont.

\begin{tabular}{|c|c|c|c|c|c|}
\hline Flavonoid Class & $\begin{array}{l}\text { Flavonoid } \\
\text { Subclass }\end{array}$ & Study Design & Dose & Results & Reference \\
\hline Baicalein & Flavone & In vivo; T1DM rats & $200 \mathrm{mg} / \mathrm{kg}$ & $\begin{array}{l}\text { Improved cardiac injury by increasing } \\
\text { cardiac antioxidant levels; prevented } \\
\text { cardiomyocyte inflammation and } \\
\text { apoptosis by via inhibition of } \\
\text { P13K/Akt pathway. }\end{array}$ & Ma et al. 2018 [73] \\
\hline Fortunellin & Flavone & $\begin{array}{l}\text { In vivo \& in vitro; } \\
\mathrm{H} 9 \mathrm{C} 2 \text { cells \& } \\
\text { diabetic mice }\end{array}$ & $\begin{array}{l}10,20 \text { and } 30 \mathrm{mg} / \mathrm{kg} \\
20,40 \& 80 \mathrm{uM}\end{array}$ & $\begin{array}{l}\text { Significantly attenuated cardiac structural } \\
\text { and functional alterations by modulating } \\
\text { cardiac inflammation and oxidative stress } \\
\text { via the NF- } \kappa \text { B pathway. }\end{array}$ & Zhao et al. 2017 [74] \\
\hline Rutin & Flavone & In vivo; T1DM rats & $50 \mathrm{mg} / \mathrm{kg}$ & $\begin{array}{l}\text { Improved diabetic phenotypes; protected } \\
\text { the heart against left ventricular } \\
\text { hypertrophy and myocardial dysfunction. }\end{array}$ & Guimaraes et al. 2015 [75] \\
\hline Diosmin & Flavone & In vivo; T1DM rats & $100 \mathrm{mg} / \mathrm{kg}$ & $\begin{array}{l}\text { Improved hyperglycemia and blood } \\
\text { pressure as well protected the heart against } \\
\text { cardiac injury, alleviated cardiac } \\
\text { inflammation by downregulating } \\
\text { pro-inflammatory cytokines, and } \\
\text { ameliorated cardiac apoptosis. }\end{array}$ & Ali et al. 2019 [76] \\
\hline Nobiletin & Flavone & In vivo; T1DM mice & $50 \mathrm{mg} / \mathrm{kg}$ & $\begin{array}{l}\text { Ameliorated cardiac dysfunction by } \\
\text { improving cardiac oxidative stress via the } \\
\text { inhibition of NADPH oxidase expression. } \\
\text { Additionally, inhibited activation of c-Jun } \\
\text { NH2-terminal kinase (JNK), P38, and } \\
\text { NF-KB in the cardiac tissue. }\end{array}$ & Zhang et al. 2016 [77] \\
\hline \multirow{3}{*}{ Kaempferol } & Flavonol & In vivo; T1DM rats & $20 \mathrm{mg} / \mathrm{kg}$ & $\begin{array}{l}\text { Improved hyperglycemia condition; } \\
\text { reduced cardiac injury and increased } \\
\text { cardiac oxidative stress status via the } \\
\text { upregulation of Nrf2. }\end{array}$ & Zhang et al. 2019 [78] \\
\hline & Flavonol & In vivo; T1DM rats & $20 \mathrm{mg} / \mathrm{kg}$ & $\begin{array}{l}\text { Improved hyperglycemia; suppressed } \\
\text { AGE-RAGE activation and suppressed } \\
\text { PKC-MAPK pathways in inducing cardiac } \\
\text { inflammation and oxidative stress. }\end{array}$ & Suchal et al. 2017 [79] \\
\hline & Flavonol & In vivo; T1DM mice & $100 \mathrm{mg} / \mathrm{kg}$ & $\begin{array}{l}\text { Significantly attenuated cardiac } \\
\text { hypertrophy by inhibiting } \\
\text { MAPK pathways. }\end{array}$ & Feng et al. 2017 [80] \\
\hline \multirow[b]{2}{*}{ Quercetin } & Flavonol & In vivo; T1DM rats & $\begin{array}{c}10,25 \text { and } \\
50 \mathrm{mg} / \mathrm{kg} / \mathrm{bw}\end{array}$ & $\begin{array}{l}\text { Protected against cardiac injury and } \\
\text { increased cardiac antioxidants levels. }\end{array}$ & Roslan et al. 2016 [81] \\
\hline & Flavonol & $\begin{array}{l}\text { In vivo; } \\
\text { high-cholesterol fed, } \\
\text { hyperglycemic rats }\end{array}$ & $0.5 \% w / w$ in rat feed & $\begin{array}{l}\text { Improved diabetic phenotype and cardiac } \\
\text { oxidative stress by upregulating } \\
\text { Nrf2 expression. }\end{array}$ & Castillo et al. 2018 [82] \\
\hline Fisetin & Flavonol & In vivo; T1DM rats & $2.5 \mathrm{mg} / \mathrm{kg}$ & $\begin{array}{l}\text { Improved diabetic phenotypes by } \\
\text { alleviating hyperglycemia and } \\
\text { hyperlipidemia; reduced cardiac injury } \\
\text { and regressed cardiac function by } \\
\text { suppressing oxidative stress, inflammation } \\
\text { and apoptosis in the diabetic hearts. }\end{array}$ & Althunibat et al. 2019 [83] \\
\hline Myricitrin & Flavonol & $\begin{array}{l}\text { In vivo \& in vitro; } \\
\text { H9c2 cells \& } \\
\text { T1DM rats }\end{array}$ & $300 \mathrm{mg} / \mathrm{kg} /$ day & $\begin{array}{l}\text { Reduced AGE-induced cardiac } \\
\text { inflammation and upregulated Nrf } 2 \text { in } \\
\text { cardiac tissue to improve oxidative } \\
\text { stress status. }\end{array}$ & Zhang et al. 2017 [84] \\
\hline Genistein & Isoflavone & In vivo; T1DM rats & 10 and $50 \mathrm{mg} / \mathrm{kg}$ & $\begin{array}{l}\text { Significantly improved cardiac function } \\
\text { and alleviated cardiac oxidative stress by } \\
\text { regulating the Nrf2/HO-1 pathway. }\end{array}$ & Jia et al. 2019 [85] \\
\hline
\end{tabular}

Preparation and processing of food may decrease flavonoid levels depending on the methods used. For example, in a recent study, orange juices were found to contain 81-200 mg/L soluble flavanones, while its content in the juice cloud concentrate was 206-644 mg/L, which suggest that the flavanones are concentrated in the juice cloud concentrate during processing and storage [86]. Accurate estimation of the average dietary intake of flavonoids is difficult, because of the wide varieties of available flavonoids and the extensive distribution in various plants and also the diverse consumption in humans. Recently, there has been an upsurge of interest in the therapeutic potential of medicinal plants, which might be due to their extract being rich in health-beneficial flavonoids.

Flavones can be found in many types of food, especially tea leaves and herbs [87]. They have a double bond in between the $\mathrm{C} 2$ and $\mathrm{C} 3$ of the flavonoid backbone and absence 
of any substitution on the $\mathrm{C} 3$ position [88]. Among commonly found flavones are nobiletin, baicalein, diosmin, apigenin, luteolin and fortunellin. Flavones are widely studied for their anti-oxidative activities and ability to scavenge ROS [89]. Apigenin, a type of flavone, was found to be able to protect endothelial tissues from inflammatory damage and preserve mitochondrial function [90]. Flavones also exhibited potent anti-inflammatory properties, contributed by regulating the toll-like receptor (TLR)/NF- $\mathrm{KB}$ pathway that is responsible for the expression of pro-inflammatory expressions [89].

Flavonols are the most abundantly found flavonoid in nature. They are characterized by the presence of a hydroxyl group in the C3 position (Figure 3), and the majority of flavonols have additional hydroxyl groups in the C5 and C7 positions [91]. Fisetin, kaempferol, quercetin, and myricetin are the most frequently found flavonols in plants, mainly in the leaves and outer parts of the plants (such as peels) [91]. Plants that are rich in flavonols are lettuce, tomatoes, grapes, onions and berries. Flavonols are always associated with their cardiovascular protective effect, mostly contributed by its potent antioxidant potential [66]. Flavonol-rich extracts of ginkgo were found to be able to provide protection against myocardial ischemia reperfusion injury in a rat model [72].

Flavanols, also referred to as flavan-3-ols or catechins, are 3-hydroxy derivatives of flavanones. Different from other flavonoids, flavanols do not have a double bond in between C2 and C3 [66]. They can be found abundantly in apples, blueberries, peaches, and bananas as well as tea leaves. Tea extracts and pure flavanols has been reported to have antioxidant, antiviral, antibacterial, and anti-cancer activities and to decrease blood pressure as well as blood glucose level. Lipid metabolism studies have revealed that tea extracts and individual flavanols lower triacylglycerol and total cholesterol concentrations and inhibit hepatic and body fat accumulation [92].

Isoflavones, another subclass of flavonoids, are often known as phytoestrogen, as they are able to bind on estrogen receptors [93]. They are chemically differed from other flavonoids in that they have hydroxyl groups in the C7 and C4 positions and also differ in the position of the B ring in C3 [63]. Isoflavones are mainly found in legumes, especially soybeans [94]. Genistein, daidzein, and glycetein are among the most commonly found isoflavones in soy, being the most widely studied isoflavones source. Genistein was found to be able to induce alterations in hormonal and metabolic pathways, influencing the affected pathogenesis of the disease [95].

Flavanones, mainly found in citrus fruits, have a dihydropyrone ring $(\mathrm{C})$ between the two aromatic rings (A and B) [66]. They differ structurally from flavones and flavanols, which both are also found widely in citrus fruits, whereby flavanones have chiral carbon atom on the $\mathrm{C} 2$ position and absence of any substitution at the C3 position of the $C$ ring [96]. The most frequently found flavanones are hesperetin and its aglycone derivative hesperedin, nanringenin, and taxifolin. Flavanone is mostly consumed from the consumption of citrus fruits and juices sourced from oranges, grapefruits, lemons, bergamots, tangerines, and kumquats. The bitter taste in the citrus peels is contributed by the rich flavanones in this part of the fruits [66]. Flavanones exert their health benefit effects via their potent antioxidant, anti-inflammatory, and lipid-lowering properties [96].

Anthocyanidins, mostly known as anthocyanins, are pigment compounds in plant that contribute to their colors. They occur mainly on the fruit peel of various fruits including grapes, raspberries, blackberries, and cranberries. The color of the anthocyanin depends on the $\mathrm{pH}$ and also by methylation or acylation at the hydroxyl groups on the $\mathrm{A}$ and $\mathrm{B}$ rings [97]. Among mostly studied anthocyanidins are cyanidin, delphinidin, malvidin, and peonidin [66]. The positively charged oxygen atom in the anthocyandin molecule makes it a potent and distinct hydrogen-donating antioxidant [98].

\section{Therapeutic Role of Flavonoid in Inhibiting DCM Development 4.1. Flavones}

Reports have shown that flavones could protect the heart against cardiac dysfunction and development of diabetic cardiomyopathy by exerting its action on various mechanisms. 
Nobiletin, mainly found in citrus peels, were found to be able to alleviate the development diabetic cardiomyopathy via inhibition of cardiomyocyte apoptosis, oxidative stress, and inflammation in rat model when given 1 week after induction of type 1 diabetes mellitus [77]. Alleviation of oxidative stress by nobiletin was via inhibition of phosphorylation of JNK and p38 MAPKs, which in turn downregulate executioner caspase 3 and preventing cardiomyocyte apoptosis. On top of that, nobiletin also suppressed the generation of a superoxide by NADPH oxidase by downregulating expression of NADPH oxidase isoforms [77]. Meanwhile, baicalein was also found to exert the same antioxidative and anti-apoptotic effects, mainly via inhibition of PI3K/Akt pathway in diabetic rats' hearts [73]. The same antioxidative protection can be seen exerted by fortunellin in high fructose-fed diabetic mice, whereby it was found to increase endogenous antioxidants production (SOD, GSH, CAT, and heme oxygenase-1) by the upregulation of Nrf2. Inhibition of Keap-1 expression was also induced by fortunellin, which in turn upregulates Nrf2, thus preventing diabetic heart injury [74]. Dudylina et al. [99] reported that rutin was able to remove even more superoxide anions compared to flavonol quercetin. They suggested that this is mainly due to the flavone having 2 hydroxyl groups on its B-ring, allowing them to scavenge superoxides more potently. The ability of rutin to scavenge superoxides exhibits the potential in limiting cardiac oxidative damage as well as preventing the excessive trigger of other pathologic pathways that lead to the progression of DCM.

Cardiac inflammation in diabetic animal models was also controlled by flavones, whereby nobiletin, baicalein, and fortunellin were found to be able to reduce the release of anti-inflammatory cytokines (TNF- $\alpha$, IL-1 $\beta$, IL-6, and IL-8) [73,74,77]. In a mouse model, fortunellin was found to reduce the phosphorylation of IкB, preventing it to degrade; thus, it inhibits the activation of NF-KB [74,100]. On top of that, diabetic-induced cardiac remodeling by fibrosis and hypertrophy was halted by diosmin and nobiletin treatment to diabetic rats $[76,77]$. Expression of cardiac hypertrophic and fibrotic markers TGF- $\beta 1$, CTGF, fibronectin, and collagen I were all significantly reduced upon treatment with both flavones. Interestingly, treatment of diosmin in diabetic rats also seems to improve signaling sensitivity of insulin, which was believed to be caused by improvement in protein metabolism and alteration in muscle and liver glycogen [76].

\subsection{Flavonols}

Similar to flavones, flavonols also control DCM development and progression via their ability to control oxidative stress, inflammation, and apoptosis and the subsequent cardiac remodeling. Persistent hyperglycemia in diabetic patients has been previously reported to be the main trigger for these maladaptive processes [4]. Fisetin, a flavonol abundantly found in fruits and vegetables such as strawberry and cucumber, was reportedly able to lower blood glucose demonstrated by the reduction of the percentage of $\mathrm{HbA} 1 \mathrm{c}$ in a diabetic rat model [83]. Feng et al. [80] also demonstrated that kaempferol treatment to diabetic rats was able to reduce the blood glucose level. This glucose-lowering effect of these flavonols was suggested to be contributed by their ability to improve insulin release via their antioxidative effects on pancreatic $\beta$-cells, which protect them against further hyperglycemia-induced destruction in type 1 diabetes mellitus [101].

Due to the large number of hydroxyl groups in its chemical structure, quercetin effectively remove superoxide anions produced by mitochondria [99]. Quercetin also reportedly improves nitric oxide bioavailability, thus reducing mitochondrial superoxide production [102]. The upregulation and activation of Nrf2 by flavonols further alleviates oxidative stress in the diabetic heart, thus protecting it against subsequent cardiomyocyte apoptosis, which persistent oxidative stress triggers [80-83,101,103]. Nrf2 will detach from Keap1 when the latter is S-nitrosylated, allowing it to translocate to the nucleus and bind to its promoter on the DNA. The binding of Nrf2 to its promoter ARE then allows for the upregulation of antioxidant genes, phase 2 detoxification enzymes (heme oxygenase-1, gamma glytamylcystein synthetase, and NADPH dehydrogenase) [104]. Moreover, inhibition of xanthine oxidase by flavonols also protects the heart against oxidative damage, 
as seen in treatment of rutin to diabetic rats. Inhibition of xanthine oxidase results in the inhibition of inducible nitric oxide synthase (iNOS) activity, generation of AGE, and lipid peroxidation [75]. Flavonol fisetin, kaempferol, and quercetin was also found to improve dyslipidemia in rat models, with a significant increase in the total cholesterol/high density lipoprotein ratio [74,83]. As hyperlipidemia has been associated with alterations of cardiac functions in diabetic conditions, especially by ROS production and lipid accumulation [105], the ability of flavonoids to improve the lipid profile showed that they could reduce cardiovascular risk in diabetic patients.

As inflammation is well correlated with the development of DCM, the ability of flavonols to inhibit this maladapative response induced by hyperglycemia further explains its cardioprotective potential. Treatment of fisetin flavonol to streptozotocin-induced diabetic rats was reportedly able to reduce the production of pro-inflammatory cytokines such as TNF- $\alpha$, IL-1 $\beta$, and IL-6 in the hearts of streptozotocin-induced rats [83]. Controlling cardiac inflammation is crucial, as persistent high levels of inflammatory cytokines would further worsen cardiac remodeling via TNF- $\alpha$ 's action on converting resident fibroblast into myofibroblasts, aside from extensive cardiomyocyte death, which is also promoted by TNF- $\alpha$ [106]. Flavonols are also reportedly able to inhibit the phosphorylation of IкB, which in normal conditions would be bound to NF- $k B$ to inactivate it, thus preventing the activation of NF- $\mathrm{KB}$ and the subsequent damaging effects it induces $[83,107]$.

Cardiac remodeling events in the diabetic heart is further exacerbated by extensive cardiomyocyte death induced by diabetic conditions. Flavonols treatment was shown to be able to control cardiomyocyte apoptosis [75,80-83,101-104]. Both fisetin and kaempferol treatments reportedly downregulated Bax, caspase 9, and caspase 3 expression as well as increased anti-apoptotic protein Bcl-2 in the treated diabetic rats' hearts [80,83]. In addition, kaempferol was found to downregulate the activation of apoptosis signal-regulating kinase 1 (ASK1) in the hearts of diabetic mice, which mediates inflammation and apoptosis via the activation of NF-KB [99]. Downregulation of ASK1 and its related components further reduces the expression of apoptotic and inflammatory related proteins. Apoptosis of cardiomyocyctes in diabetic conditions is also further aggravated by the activation of mitogen-activated protein kinase (MAPKs) via p-38 MAPK pathways. Flavonol treatment was found to be able to inhibit p-38 MAPK and activate ERK $1 / 2$ pathways, which further improves cell synthesis [79].

While cardiac remodeling comprises events that aim to preserve cardiac function of integrity, uncontrolled and excessive remodeling would result in further decline in cardiac function. Cardiac hypertrophy has been previously reported to be related to the over-activation of MAPK signaling pathways [108]. Kaempferol was found to be able to prevent the phosphorylation of ASK1, which is also the upstream regulator for both JNK and p-38 MAPK $[80,109]$, thus protecting the heart against cardiomyocyte hypertrophy.

\subsection{Flavanols}

Flavanols were found to be able to improve oxidative stress by increasing the phosphorylation of SIRT-1 [70]. Phosphorylation of SIRT-1 will deacytelate forkhead box protein O1 (FOXO1) and perixosome proliferator-activated receptor gamma coactivator (PGC)1-alpha, forming a complex that translocates into the nucleus and binds to the DNA to activate the transcription of SOD2 and catalase, thus increasing their production [70]. Alleviation of accumulated ROS was also found to be exerted by flavanol by the upregulation of phase II antioxidative enzymes, including heme oxygenase-1 (HO-1), NADPH dehydrogenase (NQO1), and manganese SOD (MnSOD) in diabetic rat's hearts [110]. Both epicatechin and epigallocatechin were found to be able to directly scavenge ROS, thus protecting against direct cardiac oxidative damage in rat models [69]. As hyperglycemia directly causes oxidative stress, the ability of flavanol to exert an anti-diabetic effect by reducing blood glucose level further shows their protection against cardiac oxidative stress in rats [69]. Epigallocatechin was found to be able to inhibit the sodium-dependent glucose transporter 1 (SGLT1) activity, which would prevent systemic glucose uptake [69,111]. 
Flavanols treatment to diabetic rats is reportedly able to reduce serum level of proinflammatory cytokines, which are all involved in the cardiac function and structure derangement in diabetes mellitus [107]. In addition, cardiomyocyte death via apoptosis was also prevented by flavanol treatment, whereby increased Bcl-2 in cardiac tissue was observed following epigallocatechin treatment, thus preventing the mitochondrial release of cytochrome $c$ and the subsequent activation of caspase 9 and the executioner caspase 3 [107]. In another study, epicatechin-rich cocoa polyphenol extract was found to be able to reduce cardiac mitochondrial superoxide production [112]. The reduction in superoxide production is linked to the increased expression of endothelial nitric oxide synthase (eNOS), which restores the bioavailability of nitric oxide. Nitric oxide alleviates mitochondrial superoxide by post-translational modification [113], and in return, ameliorating cardiac oxidative stress.

\subsection{Isoflavones}

Similar to other classes of flavonoids, isoflavones are also able to improve cardiac oxidative stress conditions, as seen in diabetic rats after given treatments of isoflavones genistein and puerarin $[85,114]$. By promoting the production of endogenous antioxidants, genistein was found to be able to reduce cardiac oxidative damage, reflected by the reduction in cardiac malondialdehyde level compared to untreated diabetic rats [85]. Activation of cardiac Nrf2 again seems to be a common target for most flavonoids as the same activation was also seen upon isoflavone treatments $[85,115]$.

Puerarin, an isoflavone commonly found in legumes and soy, was found to be able to inhibit the signaling of NF- $\mathrm{KB}$, thus impeding cardiac inflammatory response both in vivo and in vitro [115]. Reduction in the expression of pro-inflammatory cytokines further support this finding. It was suggested that upregulated MAPK signaling pathways play an important role in the activation of NF- $\mathrm{KB}$ in diabetic conditions. Different structural components are responsible for the activities of isoflavones; for example, the hydroxyl group at position 7 is required for SIRT1 activation, which is a protein deacetylase that regulates metabolism, stress responses, and aging processes [116], while the hydroxyl groups at position 5 block SIRT1 activation, and the loss of the phenyl ring at position 3 or the $4^{\prime}$-hydroxy or -methoxy substituent blocks increases SIRT1 expression [117].

\subsection{Flavanone}

Flavanone use in diabetic cardiomyopathy study has not yet widely explored; however, we can predict the outcome of its treatment by referring to studies made on its effects on other cardiac disease models. For example, naringin, a flavanone mostly found in citrus fruits, exhibited potent antioxidant effects in fructose-treated cells [118]. By modulation of AMP-activated serine/threonine protein kinase-mammalian target of rapamycin (AMPK-mTOR) signaling pathway, naringin inhibited ROS production and cardiomyocyte hypertrophy significantly. Naringin treatment was also able to suppress cardiomyocyte apoptosis, reflected in the significant decreased of caspase 9 and caspase 3 gene expressions in both in vivo and in vitro models [118], which are both more pronounced in non-treated high fructose-exposed $\mathrm{H} 9 \mathrm{c} 2$ cells.

Citrus flavanones were also found to modulate the JNK/p38 MAPK pathway, which has been previously reported to play a significant role in the development of DCM $[4,17]$, especially via the promotion of cardiomyocytes inflammation and apoptosis. Musolino et al. [17] reported that via this pathway, bergamot polyphenols, which are rich in flavanone naringin and hesperidin, were able to ameliorate insulin sensitivity along with their potent antioxidative properties, further supporting their therapeutic use for the management of DCM $[119,120]$. Hesperidin and its aglycone derivative hesperetin are both found abundantly in citrus fruits and showed to be able to protect the heart against doxorubicininduced oxidative stress by improving cardiac antioxidants levels [121]. Hesperetin exerts anti-apoptotic effects by reducing the activation of p38 MAPK and expression of caspase 3 in the LPS-treated cardiomyocytes [122]. 


\subsection{Anthocyanidin}

Similar to flavanone, studies of anthocyanidin effects on diabetic cardiomyopathy are not yet widely explored. Only a handful of studies have been completed on its treatment in diabetic cardiomyopathy conditions. As a pigment compound, anthocyanidins are found more frequently in flowers compared to fruits [97]. Treatment of roselle calyx extract, which is reportedly rich in cyanidin-3-glucoside and delphinidin, was shown to improve cardiac dysfunctions in diabetic rats [123-125]. Ex vivo treatment of this extract was also able to improve cardiac contraction and relaxation in an ex vivo cardiac function study [126]. Moreover, anthocyanin-rich purple rice extract treatment to diabetic rats was also found to be able to protect the heart against developing cardiac hypertrophy and fibrosis, thus protecting them against developing diabetic cardiomyopathy [68]. However, the pathways on which anthocyanidins acted to exert these cardioprotective effects have not yet been studied.

\section{Flavonoids in Clinical Studies}

The study of flavonoids in clinical settings has not yet been widely explored, especially for isolated flavonoid compounds. Instead, known clinical studies of flavonoid effects on health have mostly focused on the consumption of extracts or fruits that are known to be rich with flavonoids or certain isolated compounds. For example, Curtis and his team [127] studied the effect of blueberry consumption on cardiovascular diseases risk among Type 2 diabetic patients. Blueberries are known to be rich in anthocyanins. They reported that daily intake of one cup of blueberries was able to reduce diabetic cardiovascular disease risk by 12 to $15 \%$, although the consumption did not affect the insulin sensitivity. Macarro et al. [128] studied the benefits of combination of citrus fruits (grapefruit, bitter orange, and olive) that are known to be rich in flavones, on reducing the cardiovascular risk in healthy individuals. They found that the intake of flavone-rich citrus fruits was able to significantly reduce cardiovascular diseases risk. In another study, Curtis and colleagues [129] found that chronic consumption of dietary flavonoids (for three years) was able to reduce the cardiovascular risk in Type 2 diabetes post-menopausal women.

Treating and limiting the progression of DCM has been proven to be tricky due to its nature; multiple mechanisms are being triggered simultaneously in diabetic conditions, leading to the speedy deterioration of cardiac functions. Uncontrolled oxidative stress, apoptosis, and inflammation are all proven to be prompted by persistent hyperglycemic conditions. This is why, presently, controlling optimum or healthy blood glucose level either with the assistance of pharmacological drugs or by the control of diet have been the golden standard in the management of DCM [130]. In that regard, clinical studies have shown that the administration of citrus flavonoids to prediabetic subjects was able to reduce glucose level as well as systemic inflammation and oxidative stress. The 12-week treatment was also found to be able to reverse prediabetic conditions [131]. Similar findings were replicated in obese patients given with bergamot polyphenol-rich extract, with additional favorable insulin control and increased insulin sensitivity following a 90-day treatment $[132,133]$. Treatment of silymarin, of which the main constituent is flavonoid silibinin, to T2DM patients was found to be able to improve the glycemic index and lipid profile significantly [134]. On top of that, purified anthocyanin treatment was reportedly able to reduce cardiometabolic risk in prediabetic and diabetic subjects, exhibited by the promising glycemic control and improvement of lipid profile [135]. Apple polyphenol treatment for 12 weeks was also found to be able to ameliorate hyperglycemia conditions in prediabetic subjects [136]. Reduction of cardiometabolic risk was also shown following treatment of epicatechin to subjects with hypertriglyceridemia, shown by a significant reduction in the glucose level, lipid profile, and systemic inflammation [137]. The findings of these clinical studies showed the promising potential of flavonoids to be used as cardiovascular disease management, especially DCM, either by cardioprotective properties or anti-hyperglycemic effects. 
While some flavonoids share similar mechanisms of action in limiting the progression of DCM, other flavonoids may affect different routes instead. For example, fortunellin inhibits inflammation by inhibiting NF- $\mathrm{KB}$ activity [62] and the combination of this compound with fisetin would allow the control of DCM by limiting both cardiac inflammation and cardiac injury via the alleviation of oxidative damage [83]. Theoretically, the combination of flavonoids that exert protective effects via distinct pathways would be most advantageous. Studies have shown that the combination of the flavonoids apigenin and curcumin was found to be able to prevent the progression of cervical cancer cells via an antitumor effect on the cancer cells contributed by their synergistic effects [138]. In addition, chrysin and kaempferol combination was found to be able to limit in vitro inflammation by synergistically modulating the TNF- $\alpha$ pathway [139]. These findings, indeed, show that there is a potential for even more effective therapeutic effects when flavonoids are used in combination. However, presently, there is a scarcity of research focusing on this prospect. To the best of our knowledge, research that uses a combination of flavonoids on a DCM model is still lacking. With respect to the usage of flavonoids combination for therapy, there is also a possible contrainteraction between different flavonoids when used in combination, as well as a possible contrainteraction when flavonoids are taken with pharmacological drugs [140]. This unascertained possibility needs to be further studied.

\section{Conclusions}

From our review, it is clear that hyperglycemia-induced persistent oxidative stress exerts the worst effects on the cardiac function in diabetic cardiac oxidative stress, which not only causes direct oxidative damage on the cardiac tissue, but it also propagates cardiac inflammation and apoptosis as adaptive responses, which quickly turns maladaptive when the hyperglycemic condition is not managed, causing a progression of diabetic cardiomyopathy towards an advanced stage. Flavonoid treatments from all classes were shown to be beneficial towards treating and limiting the progression of diabetic cardiomyopathy by mediating hyperglycemia-induced cardiac oxidative stress, inflammation, and apoptosis (Figure 4). All flavonoids seem to share the same effects and targets on alleviating oxidative stress, whereby they were all proven to upregulate the Nrf2 pathway by increasing the endogenous antioxidants levels, assisting the heart to combat the hyperglycemia-induced oxidative stress. They were also shown to inhibit NF- $\kappa B$ pathways in inducing cardiac inflammation. These similar effects by different flavonoids might be due to them sharing a similar chemical backbone. Pre-clinical studies on how flavonoids are able to improve regressed cardiac function in diabetic conditions is very promising for the management of DCM; however, clinical testing on their effects in humans is still lacking and not widely conducted.

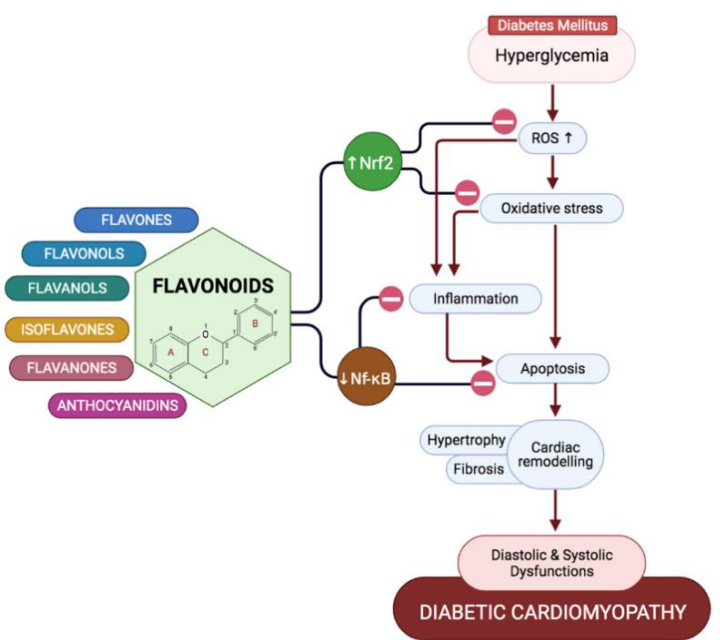

Figure 4. Potential of flavonoids in ameliorating diabetic cardiomyopathy, derived from their ability to combat diabetes-induced oxidative stress, inflammation, and apoptosis, which all play key roles in the structural and functional alterations in diabetic cardiomyopathy. 
Author Contributions: Conceptualization, F.F.J. and S.B.B.; resources, F.F.J. and S.B.B.; writingoriginal draft preparation, F.F.J.; writing—review and editing, S.B.B.; I.S.T.; Z.A.H. and S.Z.; supervision, S.B.B. The authors have contributed substantially to the work reported. All authors have read and agreed to the published version of the manuscript.

Funding: This research was funded by the Ministry of Education Malaysia, grant number FRGS/1/ 2019/STG03/UKM/01/3.

Institutional Review Board Statement: Not applicable.

Informed Consent Statement: Not applicable.

Data Availability Statement: No new data were created or analyzed in this study. Data sharing is not applicable to this article.

Conflicts of Interest: The authors declare no conflict of interest. The funders had no role in the design of the study; in the collection, analyses, or interpretation of data; in the writing of the manuscript, or in the decision to publish the results.

\section{Abbreviations}

$\begin{array}{ll}\text { DCM } & \text { Diabetic cardiomyopathy } \\ \text { DPP-4 } & \text { Dipeptidyl peptidase-4 } \\ \text { GLP-1 } & \text { Glucagon-like peptide-1 } \\ \text { SGLT2 } & \text { Sodium-dependent glucose transporter-2 } \\ \text { AE } & \text { Aglycone equivalent } \\ \text { ESC } & \text { European Society of Cardiology } \\ \text { ROS } & \text { Reactive oxygen species } \\ \text { AGE } & \text { Advanced glycation end products } \\ \text { PKC } & \text { Protein kinase C } \\ \text { DAG } & \text { Diacylglycerol } \\ \text { NADPH } & \text { Nicotinamide adenine dinucleotide phosphate } \\ \text { MAPK } & \text { Mitogen-activated protein kinase } \\ \text { ERK } & \text { Extracellular-regulated kinase } \\ \text { JNK } & \text { c-Jun N-terminal kinase } \\ \text { SOD } & \text { Superoxide dismutase } \\ \text { H }{ }_{2} \mathrm{O}_{2} & \text { Hydrogen peroxide } \\ \text { RAGE } & \text { Receptor for AGE } \\ \text { Keap1 } & \text { Kelch-like ECH-associated protein } \\ \text { IL } & \text { Interleukin } \\ \text { SIRT-1 } & \text { Sirtuin-1 } \\ \text { TLR-4 } & \text { Toll-like receptor 4 } \\ \text { TGF- } \beta & \text { Tumor growth factor } \beta \\ \text { Nrf2 } & \text { Nuclear erythroid 2-related factor 2 } \\ \text { CTGF } & \text { Connective tissue growth factor } \\ \text { iNOS } & \text { Inducible nitric oxide synthase } \\ \text { TNF- } \alpha & \text { Tumor necrosis factor- } \alpha \\ \text { ASK1 } & \text { Apoptosis signal-regulating kinase 1 } \\ \text { FOXO1 } & \text { Forkhead box protein O1 } \\ \text { NQO1 } & \text { NADPH dehydrogenase } \\ \text { MnSOD } & \text { Manganese SOD } \\ \text { HO-1 } & \text { Heme oxygenase-1 } \\ \text { SGLT1 } & \text { Sodium-dependent glucose transporter 1 } \\ \text { AMPK-mTOR } & \text { AMP-activated serine/threonine protein kinase- mammalian target-of-rapamycin } \\ & \end{array}$

\section{References}

1. International Diabetes Federation. IDF Diabetes Atlas, 9th ed.; International Diabetes Federation: Brussels, Belgium, 2019.

2. Einarson, T.R.; Acs, A.; Ludwig, C.; Panton, U.H. Prevalence of cardiovascular disease in type 2 diabetes: A systematic literature review of scientific evidence from across the world in 2007-2017. Cardiovasc. Diabetol. 2018, 17, 1-19. [CrossRef] [PubMed] 
3. Institute for Public Health (IPH). National Health and Morbidity Survey 2015: Non-Communicable Diseases, Risk Factors E Other Health Problems; Insitute for Public Health, Ministry of Health Malaysia: Kuala Lumpur, Malaysia, 2015; Volume II.

4. Jia, G.; Hill, M.A.; Sowers, J.R. Diabetic Cardiomyopathy: An Update of Mechanisms Contributing to This Clinical Entity. Circ. Res. 2018, 122, 624-638. [CrossRef] [PubMed]

5. Paolillo, S.; Marsico, F.; Prastaro, M.; Renga, F.; Esposito, L.; De Martino, F. Diabetic cardiomyopathy: Definition, diagnosis, and therapeutic implications. Heart Fail Clin. 2019, 15, 341-347. [CrossRef] [PubMed]

6. Lorenzo-Almorós, A.; Tuñón, J.; Orejas, M.; Cortés, M.; Egido, J.; Lorenzo, Ó. Diagnostic approaches for diabetic cardiomyo-pathy. Cardiovasc. Diabetol. 2017, 16, 28. [CrossRef]

7. Borghetti, G.; Von Lewinski, D.; Eaton, D.M.; Sourij, H.; Houser, S.R.; Wallner, M. Diabetic Cardiomyopathy: Current and Future Therapies. Beyond Glycemic Control. Front. Physiol. 2018, 9, 9. [CrossRef]

8. Kenny, H.C.; Abel, E.D. Heart Failure in Type 2 Diabetes Mellitus. Circ. Res. 2019, 124, 121-141. [CrossRef]

9. Cleland, S.J.; Fisher, B.M.; Colhoun, H.M.; Sattar, N.; Petrie, J.R. Insulin resistance in type 1 diabetes: What is 'double diabetes' and what are the risks? Diabetologia 2013, 56, 1462-1470. [CrossRef] [PubMed]

10. El Mouhayyar, C.; Riachy, R.; Khalil, A.B.; Eid, A.; Azar, S. SGLT2 Inhibitors, GLP-1 Agonists, and DPP-4 Inhibitors in Diabetes and Microvascular Complications: A Review. Int. J. Endocrinol. 2020, 2020, 1762164. [CrossRef]

11. Xiao, J. Dietary Flavonoid Aglycones and Their Glycosides: Which Show Better Biological Significance? Crit. Rev. Food Sci. Nutr. 2015, 57. [CrossRef] [PubMed]

12. Loh, Y.C.; Chan, S.Y.; Tew, W.Y.; Oo, C.W.; Yam, M.F. New flavonoid-based compound synthesis strategy for antihypertensive drug development. Life Sci. 2020, 249, 117512. [CrossRef]

13. Bailly, C. Molecular and cellular basis of the anticancer activity of the prenylated flavonoid icaritin in hepatocellular carcinoma. Chem. Biol. Interact. 2020, 325, 109124. [CrossRef] [PubMed]

14. Qiu, Z.P.; Lin, L.; Dai, N.; Li, J.J.; Chi, Q.; Liu, Q.H.; Zhu, J.; Zhang, H.H. Flavonoid extract of hawthorn (Crataegus oxyacantha L.) fruit alleviates oxidative stress, inflammation and vascular dysfunction in L-NAME-induced hypertensive rats. J. Biol. Regul. Homeost. Agents 2020, 34, 2271-2276. [PubMed]

15. Ghorbani, A. Mechanisms of antidiabetic effects of flavonoid rutin. Biomed. Pharmacother. 2017, 96, 305-312. [CrossRef] [PubMed]

16. Musolino, V.; Gliozzi, M.; Scarano, F.; Bosco, F.; Scicchitano, M.; Nucera, S.; Carresi, C.; Ruga, S.; Zito, M.C.; Maiuolo, J.; et al. Bergamot Polyphenols Improve Dyslipidemia and Pathophysiological Features in a Mouse Model of Non-Alcoholic Fatty Liver Disease. Sci. Rep. 2020, 10, 1-14. [CrossRef] [PubMed]

17. Garcia, J.P.; Santana, A.; Baruqui, D.L.; Suraci, N. The Cardiovascular effects of chocolate. Rev. Cardiovasc. Med. 2018, 19, 123-127. [CrossRef] [PubMed]

18. Maleki, S.J.; Crespo, J.F.; Cabanillas, B. Anti-inflammatory effects of flavonoids. Food Chem. 2019, 299, 125124. [CrossRef] [PubMed]

19. Yu, H.; Chen, B.; Ren, Q. Baicalin relieves hypoxia-aroused H9c2 cell apoptosis by activating Nrf2/HO-1-mediated HIF1 $\alpha /$ BNIP3 pathway. Artif. Cells Nanomed. Biotechnol. 2019, 47, 3657-3663. [CrossRef]

20. Rubler, S.; Dlugash, J.; Yuceoglu, Y.Z.; Kumral, T.; Branwood, A.W.; Grishman, A. New type of cardiomyopathy associated with diabetic glomerulosclerosis. Am. J. Cardiol. 1972, 30, 595-602. [CrossRef]

21. Seferovic, P.M.; Paulus, W.J. Clinical diabetic cardio- myopathy: A two-faced disease with restrictive and dilated phenotypes. Eur. Heart J. 2015, 36, 1718-1727. [CrossRef]

22. Ritchie, R.H.; Irvine, J.C.; Rosenkranz, A.C.; Patel, R.; Wendt, I.R.; Horowitz, J.D.; Kemp-Harper, B.K. Exploiting cGMP-based therapies for the prevention of left ventricular hypertrophy: NO* and beyond. Pharmacol. Therapeut. 2009, 124, 279-300. [CrossRef] [PubMed]

23. van Empel, V.P.; De Windt, L.J. 2Myocyte hypertrophy and apoptosis: A balancing act. Cardiovasc. Res. 2004, 63, 487-499. [CrossRef] [PubMed]

24. Eguchi, K.; Boden-Albala, B.; Jin, Z.; Rundek, T.; Sacco, R.L.; Homma, S.; Di Tullio, M.R. Association Between Diabetes Mellitus and Left Ventricular Hypertrophy in a Multiethnic Population. Am. J. Cardiol. 2008, 101, 1787-1791. [CrossRef] [PubMed]

25. Nakamura, M.; Sadoshima, J. Mechanisms of physiological and pathological cardiac hypertrophy. Nat. Rev. Cardiol. 2018, 15, 387-407. [CrossRef] [PubMed]

26. Jubaidi, F.F.; Zainalabidin, S.; Mariappan, V.; Budin, S.B. Mitochondrial Dysfunction in Diabetic Cardiomyopathy: The Possible Therapeutic Roles of Phenolic Acids. Int. J. Mol. Sci. 2020, 21, 6043. [CrossRef] [PubMed]

27. Frangogiannis, N.G. The Extracellular Matrix in Ischemic and Nonischemic Heart Failure. Circ. Res. 2019, 125, 117-146. [CrossRef] [PubMed]

28. Gliozzi, M.; Scarano, F.; Musolino, V.; Carresi, C.; Scicchitano, M.; Ruga, S.; Zito, M.C.; Nucera, S.; Bosco, F.; Maiuolo, J.; et al. Role of TSPO/VDAC1 Upregulation and Matrix Metalloproteinase-2 Localization in the Dysfunctional Myocardium of Hypergly-caemic Rats. Int. J. Mol. Sci. 2020, 21, 7432. [CrossRef]

29. Russo, I.; Frangogiannis, N.G. Diabetes-associated cardiac fibrosis: Cellular effectors, molecular mechanisms and therapeutic opportunities. J. Mol. Cell. Cardiol. 2016, 90, 84-93. [CrossRef] [PubMed]

30. Paul, S.; Ali, A.; Katare, R. Molecular complexities underlying the vascular complications of diabetes mellitus-A comprehensive review. J. Diabetes Complicat. 2020, 34, 107613. [CrossRef] 
31. Falcão-Pires, I.; Leite-Moreira, A.F. Diabetic cardiomyopathy: Understanding the molecular and cellular basis to progress in diagnosis and treatment. Hear. Fail. Rev. 2011, 17, 325-344. [CrossRef] [PubMed]

32. Fiorentino, T.V.; Prioletta, A.; Zuo, P.; Folli, F. Hyperglycemia-induced oxidative stress and its role in diabetes mellitus related cardiovascular diseases. Curr. Pharm. Des. 2013, 19, 5695-5703. [CrossRef]

33. Othman, A.I.; Elkomy, M.M.; El-Missiry, M.; Dardor, M. Epigallocatechin-3-gallate prevents cardiac apoptosis by modulating the intrinsic apoptotic pathway in isoproterenol-induced myocardial infarction. Eur. J. Pharmacol. 2017, 794, 27-36. [CrossRef] [PubMed]

34. Al-Rasheed, N.M.; Al-Rasheed, N.M.; Hasan, I.H.; Al-Amin, M.A.; Al-Ajmi, H.N.; Mohamad, R.A.; Mahmoud, A.M. Simvastatin Ameliorates Diabetic Cardiomyopathy by Attenuating Oxidative Stress and Inflammation in Rats. Oxidative Med. Cell. Longev. 2017, 2017, 1-13. [CrossRef]

35. Atta, M.S.; El-Far, A.H.; Farrag, A.F.; Abdel-Daim, M.M.; Al Jaouni, S.K.; Mousa, S.A. Thymoquinone attenuates cardiomyo-pathy in streptozotocin-treated diabetic rats. Oxid. Med. Cell Longev. 2018, 2018, 7845681. [CrossRef] [PubMed]

36. Geraldes, P.; King, G.L. Activation of Protein Kinase C Isoforms and Its Impact on Diabetic Complications. Circ. Res. 2010, 106, 1319-1331. [CrossRef] [PubMed]

37. Singh, R.M.; Cummings, E.; Pantos, C.; Singh, J. Protein kinase C and cardiac dysfunction: A review. Hear. Fail. Rev. 2017, 22, 843-859. [CrossRef] [PubMed]

38. Gallo, S.; Vitacolonna, A.; Bonzano, A.; Comoglio, P.; Crepaldi, T. ERK: A Key Player in the Pathophysiology of Cardiac Hy-pertrophy. Int. J. Mol. Sci. 2019, 20, 2164. [CrossRef] [PubMed]

39. Wang, S.; Ding, L.; Ji, H.; Xu, Z.; Liu, Q.; Zheng, Y. The Role of p38 MAPK in the Development of Diabetic Cardiomyopathy. Int. J. Mol. Sci. 2016, 17, 1037. [CrossRef]

40. Volpe, C.M.O.; Villar-Delfino, P.H.; Dos Anjos, P.M.F.; Nogueira-Machado, J.A. Cellular death, reactive oxygen species (ROS) and diabetic complications. Cell Death Dis. 2018, 9, 119. [CrossRef]

41. Jia, G.; Demarco, V.G.; Sowers, J.R. Insulin resistance and hyperinsulinaemia in diabetic cardiomyopathy. Nat. Rev. Endocrinol. 2016, 12, 144-153. [CrossRef] [PubMed]

42. Ge, Z.-D.; Lian, Q.; Mao, X.; Xia, Z. Current Status and Challenges of NRF2 as a Potential Therapeutic Target for Diabetic Cardiomyopathy. Int. Hear. J. 2019, 60, 512-520. [CrossRef] [PubMed]

43. Kim, H.-J.; Nel, A.E. The Role of Phase II Antioxidant Enzymes in Protecting Memory T Cells from Spontaneous Apoptosis in Young and Old Mice. J. Immunol. 2005, 175, 2948-2959. [CrossRef] [PubMed]

44. Ni, R.; Cao, T.; Xiong, S.; Ma, J.; Fan, G.-C.; Lacefield, J.C.; Lu, Y.; Le Tissier, S.; Peng, T. Therapeutic inhibition of mitochondrial reactive oxygen species with mito-TEMPO reduces diabetic cardiomyopathy. Free Radic. Biol. Med. 2016, 90, 12-23. [CrossRef] [PubMed]

45. Prabhu, S.D.; Frangogiannis, N.G. The Biological Basis for Cardiac Repair After Myocardial Infarction. Circ. Res. 2016, 119, 91-112. [CrossRef] [PubMed]

46. Frieler, R.A.; Mortensen, R.M. Immune cell and other noncardiomyocyte regulation ofcardiac hypertrophy and remodeling. Circulation 2015, 131, 1019-1103. [CrossRef]

47. Tourki, B.; Halade, G. Leukocyte diversity in resolving and nonresolving mechanisms of cardiac remodeling. FASEB J. 2017, 31, 4226-4239. [CrossRef]

48. Sulaiman, M.; Matta, M.J.; Sunderesan, N.R.; Gupta, M.P.; Periasamy, M.; Gupta, M. Resveratrol, an activator of SIRT1, upregulates sarcoplasmic calcium ATPase and improves cardiac function in diabetic cardiomyopathy. Am. J. Physiol. Heart Circ. Physiol. 2010, 298, H833-H843. [CrossRef] [PubMed]

49. Abdul, Y.; Abdelsaid, M.; Li, W.; Webb, R.C.; Sullivan, J.C.; Dong, G.; Ergul, A. Inhibition of Toll-Like Receptor-4 (TLR-4) Improves Neurobehavioral Outcomes After Acute Ischemic Stroke in Diabetic Rats: Possible Role of Vascular Endothelial TLR-4. Mol. Neurobiol. 2018, 56, 1607-1617. [CrossRef]

50. Diaz-Meco, M.T.; Moscat, J. The atypical PKCs in inflammation: NF-kB and beyond. Immunol. Rev. 2012, 246, 154-167. [CrossRef] [PubMed]

51. Guzik, T.J.; Mussa, S.; Gastaldi, D.; Sadowski, J.; Ratnatunga, C.; Pillai, R.; Channon, K.M. Mechanisms of increased vascular superoxide production in human diabetes mellitus: Role of $\mathrm{NAD}(\mathrm{P}) \mathrm{H}$ oxidase and endothelial nitric oxide synthase. Circulation 2002, 105, 1656-1662. [CrossRef] [PubMed]

52. Baker, R.G.; Hayden, M.S.; Ghosh, S. NF-kappaB, inflammation, and metabolic disease. Cell Metab. 2011, 13, 11-22. [CrossRef]

53. Chen, Y.; Hua, Y.; Li, X.; Arslan, I.M.; Zhang, W.; Meng, G. Distinct Types of Cell Death and the Implication in Diabetic Car-diomyopathy. Front. Pharmacol. 2020, 11, 42. [CrossRef] [PubMed]

54. D'Arcy, M.S. Cell death: A review of the major forms of apoptosis, necrosis and autophagy. Cell Biol. Int. 2019, 43, 582-592. [CrossRef] [PubMed]

55. Su, D.; Gao, Q.; Guan, L.; Sun, P.; Li, Q.; Shi, C.; Ma, X. Downregulation of SOX11 in fetal heart tissue, under hyperglycemic environment, mediates cardiomyocytes apoptosis. J. Biochem. Mol. Toxicol. 2021, 35, 22629. [CrossRef] [PubMed]

56. Su, D.; Song, J.X.; Gao, Q.; Guan, L.; Li, Q.; Shi, C.; Ma, X. Cited2 participates in cardiomyocyte apoptosis and maternal dia-betes-induced congenital heart abnormality. Biochem. Biophys. Res. Commun. 2016, 479, 887-892. [CrossRef] [PubMed]

57. Davargaon, R.S.; Sambe, A.D.; Muthangi, S.V.V. Trolox prevents high glucose-induced apoptosis in rat myocardial H9c2 cells by regulating GLUT-4 and antioxidant defense mechanism. IUBMB Life 2019, 71, 1876-1895. [CrossRef] [PubMed] 
58. Huang, M.L.; Chiang, S.; Kalinowski, D.S.; Bae, D.H.; Sahni, S.; Richardson, D.R. The role of the antioxidant response in mito-chondrial dysfunction in degenerative diseases: Cross-talk between antioxidant defense, autophagy, and apoptosis. Oxid. Med. Cell. Longev. 2019, 2019, 6392763. [CrossRef]

59. Liu, Y.; Zheng, W.; Pan, Y.; Hu, J. Low expression of miR-186-5p regulates cell apoptosis by targeting toll-like receptor 3 in high glucose-induced cardiomyocytes. J. Cell Biochem. 2019, 120, 9532-9538. [CrossRef] [PubMed]

60. Rajesh, M.; Mukhopadhyay, P.; Bátkai, S.; Patel, V.; Saito, K.; Matsumoto, S.; Kashiwaya, Y.; Horváth, B.; Mukhopadhyay, B.; Becker, L.; et al. Cannabidiol Attenuates Cardiac Dysfunction, Oxidative Stress, Fibrosis, and Inflammatory and Cell Death Signaling Pathways in Diabetic Cardiomyopathy. J. Am. Coll. Cardiol. 2010, 56, 2115-2125. [CrossRef] [PubMed]

61. Anderson, E.J.; Rodriguez, E.; Anderson, C.A.; Thayne, K.; Chitwood, W.R.; Kypson, A.P. Increased propensity for cell death in diabetic human heart is mediated by mitochondrial-dependent pathways. Am. J. Physiol. Circ. Physiol. 2011, 300, H118-H124. [CrossRef] [PubMed]

62. Zhao, P.; Sun, M. Aquaporin in the proliferation and apoptosis of diabetic myocardial cells. Genet. Mol. Res. 2015, 14, 17366-17372. [CrossRef] [PubMed]

63. Wang, Y.; Sun, H.; Zhang, J.; Xia, Z.; Chen, W. Streptozotocin-induced diabetic cardiomyopathy in rats: Ameliorative effect of PIPERINE via Bcl2, Bax/Bcl2, and caspase-3 pathways. Biosci. Biotechnol. Biochem. 2020, 84, 2533-2544. [CrossRef] [PubMed]

64. Kumar, S.; Pandey, A.K. Chemistry and Biological Activities of Flavonoids: An Overview. Sci. World J. 2013, 2013, 1-16. [CrossRef]

65. Wang, T.-Y.; Li, Q.; Bi, K.-S. Bioactive flavonoids in medicinal plants: Structure, activity and biological fate. Asian J. Pharm. Sci. 2018, 13, 12-23. [CrossRef] [PubMed]

66. Panche, A.N.; Diwan, A.D.; Chandra, S.R. Flavonoids: An overview. J. Nutr. Sci. 2016, 5, e47. [CrossRef] [PubMed]

67. Luo, Y.; Zhang, S.; Wang, J.; Zhao, H. Effects of three flavonoids from an ancient traditional Chinese medicine Radix puerariae on geriatric diseases. Brain Circ. 2018, 4, 174-184. [CrossRef]

68. Chen, Y.F.; Shibu, M.A.; Fan, M.J.; Chen, M.C.; Viswanadha, V.P.; Lin, Y.L.; Lai, C.H.; Lin, K.H.; Ho, T.J.; Kuo, W.W.; et al. Purple rice anthocyanin extract protects cardiac function in STZ-induced diabetes rat hearts by inhibiting cardiac hy-pertrophy and fibrosis. J. Nutr. Biochem. 2016, 31, 98-105. [CrossRef] [PubMed]

69. Othman, A.I.; El-Sawi, M.R.; El-Missiry, M.A.; Abukhalil, M.H. Epigallocatechin-3-gallate protects against diabetic cardiomyopathy through modulating the cardiometabolic risk factors, oxidative stress, inflammation, cell death and fibrosis in streptozotocin-nicotinamide-induced diabetic rats. Biomed. Pharmacother. 2017, 94, 362-373. [CrossRef] [PubMed]

70. Taub, P.R.; Ramirez-Sanchez, I.; Ciaraldi, T.P.; Perkins, G.; Murphy, A.N.; Naviaux, R.; Hogan, M.; Maisel, A.S.; Henry, R.R.; Ceballos, G.; et al. Alterations in Skeletal Muscle Indicators of Mitochondrial Structure and Biogenesis in Patients with Type 2 Diabetes and Heart Failure: Effects of Epicatechin Rich Cocoa. Clin. Transl. Sci. 2012, 5, 43-47. [CrossRef] [PubMed]

71. Li, L.; Luo, W.; Qian, Y.; Zhu, W.; Qian, J.; Li, J.; Jin, Y.; Xu, X.; Liang, G. Luteolin protects against diabetic cardiomyopathy by inhibiting NF-kB-mediated inflammation and activating the Nrf2-mediated antioxidant responses. Phytomedicine 2019, 59, 152774. [CrossRef] [PubMed]

72. Xiao, C.; Xia, M.-L.; Wang, J.; Zhou, X.-R.; Lou, Y.-Y.; Tang, L.-H.; Zhang, F.-J.; Yang, J.-T.; Qian, L.-B. Luteolin Attenuates Cardiac Ischemia/Reperfusion Injury in Diabetic Rats by Modulating Nrf2 Antioxidative Function. Oxidative Med. Cell. Longev. 2019, 2019, 1-9. [CrossRef] [PubMed]

73. Ma, L.; Li, X.P.; Ji, H.S.; Liu, Y.F.; Li, E.Z. Baicalein Protects Rats with Diabetic Cardiomyopathy Against Oxidative Stress and Inflammation Injury via Phosphatidylinositol 3-Kinase (PI3K)/AKT Pathway. Med. Sci. Monit. 2018, 24, 5368-5375. [CrossRef] [PubMed]

74. Zhao, C.; Zhang, Y.; Liu, H.; Li, P.; Zhang, H.; Cheng, G. Fortunellin protects against high fructose-induced diabetic heart injury in mice by suppressing inflammation and oxidative stress via AMPK/Nrf-2 pathway regulation. Biochem. Biophys. Res. Commun. 2017, 490, 552-559. [CrossRef] [PubMed]

75. Guimaraes, J.F.C.; Muzio, B.P.; Rosa, C.M.; Nascimento, A.F.; Sugizaki, M.M.; Fernandes, A.A.H.; Cicogna, A.C.; Padovani, C.R.; Okoshi, M.P.; Okoshi, K. Rutin administration attenuates myocardial dysfunction in diabetic rats. Cardiovasc. Diabetol. 2015, 14, 90. [CrossRef] [PubMed]

76. Ali, T.M.; Abo-Salem, O.M.; El Esawy, B.H.; El Askary, A. The Potential Protective Effects of Diosmin on Streptozoto-cin-Induced Diabetic Cardiomyopathy in Rats. Am. J. Med. Sci. 2020, 359, 32-41. [CrossRef] [PubMed]

77. Zhang, N.; Yang, Z.; Xiang, S.-Z.; Jin, Y.-G.; Wei, W.-Y.; Bian, Z.-Y.; Deng, W.; Tang, Q.-Z. Nobiletin attenuates cardiac dysfunction, oxidative stress, and inflammatory in streptozotocin: Induced diabetic cardiomyopathy. Mol. Cell. Biochem. 2016, 417, 87-96. [CrossRef]

78. Zhang, L.; Guo, Z.; Wang, Y.; Geng, J.; Han, S. The protective effect of kaempferol on heart via the regulation of Nrf2, NF- $k \beta$, and PI3K/Akt/GSK-3 $\beta$ signaling pathways in isoproterenol-induced heart failure in diabetic rats. Drug Dev. Res. 2019, 80, 294-309. [CrossRef] [PubMed]

79. Suchal, K.; Malik, S.; Khan, S.I.; Malhotra, R.K.; Goyal, S.N.; Bhatia, J.; Ojha, S.; Arya, D.S. Molecular Pathways Involved in the Amelioration of Myocardial Injury in Diabetic Rats by Kaempferol. Int. J. Mol. Sci. 2017, 18, 1001. [CrossRef]

80. Feng, H.; Cao, J.; Zhang, G.; Wang, Y. Kaempferol Attenuates Cardiac Hypertrophy via Regulation of ASK1/MAPK Signaling Pathway and Oxidative Stress. Planta Med. 2017, 83, 837-845. [CrossRef]

81. Roslan, J.; Giribabu, N.; Karim, K.; Salleh, N. Quercetin ameliorates oxidative stress, inflammation and apoptosis in the heart of streptozotocin-nicotinamide-induced adult male diabetic rats. Biomed. Pharmacother. 2017, 86, 570-582. [CrossRef] [PubMed] 
82. Castillo, R.L.; Herrera, E.A.; Gonzalez-Candia, A.; Reyes-Farias, M.; de la Jara, N.; Peña, J.P.; Carrasco-Pozo, C. Quercetin Prevents Diastolic Dysfunction Induced by a High-Cholesterol Diet: Role of Oxidative Stress and Bioenergetics in Hypergly-cemic Rats. Oxid. Med. Cell. Longev. 2018, 2018, 7239123. [CrossRef] [PubMed]

83. Althunibat, O.Y.; Al Hroob, A.M.; Abukhalil, M.H.; Germoush, M.O.; Bin-Jumah, M.; Mahmoud, A.M. Fisetin ameliorates oxidative stress, inflammation and apoptosis in diabetic cardiomyopathy. Life Sci. 2019, 221, 83-92. [CrossRef]

84. Zhang, B.; Shen, Q.; Chen, Y.; Pan, R.; Kuang, S.; Liu, G.; Sun, G.; Sun, X. Myricitrin Alleviates Oxidative Stress-induced Inflammation and Apoptosis and Protects Mice against Diabetic Cardiomyopathy. Sci. Rep. 2017, 7, 44239. [CrossRef] [PubMed]

85. Jia, Q.; Wang, Y.; Liu, X.; Ma, S.; Yang, R. Effects of genistein on Nrf2/HO-1 pathway in myocardial tissues of diabetic rats. Zhong Nan Da Xue Xue Bao Yi Xue Ban 2019, 44, 850-856. [PubMed]

86. Gil-Izquierdo, A.; Gil, M.I.; Ferreres, F. Effect of Processing Techniques at Industrial Scale on Orange Juice Antioxidant and Beneficial Health Compounds. J. Agric. Food Chem. 2002, 50, 5107-5114. [CrossRef] [PubMed]

87. Hostetler, G.L.; A Ralston, R.; Schwartz, S.J. Flavones: Food Sources, Bioavailability, Metabolism, and Bioactivity. Adv. Nutr. 2017, 8, 423-435. [CrossRef] [PubMed]

88. Martens, S.; Mithöfer, A. Flavones and flavone synthases. Phytochemistry 2005, 66, 2399-2407. [CrossRef]

89. Jiang, N.; Doseff, A.I.; Grotewold, E. Flavones: From Biosynthesis to Health Benefits. Plants 2016, 5, 27. [CrossRef]

90. Duarte, S.; Arango, D.; Parihar, A.; Hamel, P.; Yasmeen, R.; Doseff, A.I. Apigenin protects endothelial cellsfrom lipopolysaccharide (LPS)-induced inflammation by decreasing caspase-3 activation and modulatingmitochondrial function. Int. J. Mol. Sci. 2013, 14, 17664-17679. [CrossRef] [PubMed]

91. Pietta, P.; Minoggio, M.; Bramati, L. Plant Polyphenols: Structure, Occurrence and Bioactivity. In Studies in Natural Products Chemistry; Part I; Rahman, A., Ed.; Elsevier: New York, NY, USA, 2003; Volume 28, pp. 257-312.

92. Nagao, T.; Hase, T.; Tokimitsu, I. A green tea extract high in catechins reduces body fat and cardiovascular risks in humans. Obes. Silver Spring 2007, 15, 1473-1483. [CrossRef] [PubMed]

93. Kř́žová, L.; Dadáková, K.; Kašparovská, J.; Kašparovský, T. Isoflavones. Molecules 2019, 24, 1076. [CrossRef] [PubMed]

94. Herrero, M.; Plaza, M.; Cifuentes, A.; Ibáñez, E. Extraction Techniques for the Determination of Phenolic Compounds in Food. In Comprehensive Sampling and Sample Preparation; Pawliszyn, J., Ed.; Academic Press: Cambridge, MA, USA, 2012; pp. 159-180.

95. Szkudelska, K.; Nogowski, L. Genistein-a dietary com- pound inducing hormonal and metabolic changes. J. Steroid Biochem. Mol. Biol. 2007, 105, 37-45. [CrossRef] [PubMed]

96. Barreca, D.; Gattuso, G.; Bellocco, E.; Calderaro, A.; Trombetta, D.; Smeriglio, A.; Laganà, G.; Daglia, M.; Meneghini, S.; Nabavi, S.M. Flavanones: Citrus phytochemical with health-promoting properties. BioFactors 2017, 43, 495-506. [CrossRef] [PubMed]

97. Khoo, H.E.; Azlan, A.; Tang, S.T.; Lim, S.M. Anthocyanidins and anthocyanins: Colored pigments as food, pharmaceutical ingredients, and the potential health benefits. Food Nutr. Res. 2017, 61, 1361779. [CrossRef]

98. Bueno, J.M.; Sáez-Plaza, P.; Ramos-Escudero, F.; Jiménez, A.M.; Fett, R.; Asuero, A.G. Analysis and Antioxidant Capacity of Anthocyanin Pigments. Part II: Chemical Structure, Color, and Intake of Anthocyanins. Crit. Rev. Anal. Chem. 2012, 42, 126-151. [CrossRef]

99. Dudylina, A.L.; Ivanova, M.V.; Shumaev, K.B.; Ruuge, E.K. Superoxide Formation in Cardiac Mitochondria and Effect of Phenolic Antioxidants. Cell Biophys. 2018, 77, 99-107. [CrossRef] [PubMed]

100. Moens, U.; Kostenko, S.; Sveinbjørnsson, B. The Role of Mitogen-Activated Protein Kinase-Activated Protein Kinases (MAPKAPKs). in Inflammation. Genes 2013, 4, 101-133. [CrossRef]

101. Shi, G.-J.; Li, Y.; Cao, Q.-H.; Wu, H.-X.; Tang, X.-Y.; Gao, X.-H.; Yu, J.-Q.; Chen, Z.; Yang, Y. In vitro and in vivo evidence that quercetin protects against diabetes and its complications: A systematic review of the literature. Biomed. Pharmacother. 2019, 109, 1085-1099. [CrossRef] [PubMed]

102. Calabró, V.; Litterio, M.C.; Fraga, C.G.; Galleano, M.; Piotrkowski, B. Effects of quercetin on heart nitric oxide metabolism in 1-NAME treated rats. Arch. Biochem. Biophys. 2018, 647, 47-53. [CrossRef]

103. Liao, H.H.; Zhu, J.X.; Feng, H.; Ni, J.; Zhang, N.; Chen, S.; Liu, H.J.; Yang, Z.; Deng, W.; Tang, Q.Z. Myricetin Possesses Po-tential Protective Effects on Diabetic Cardiomyopathy through Inhibiting IкB $\alpha / \mathrm{NF} \kappa \mathrm{B}$ and Enhancing Nrf2/HO-1. Oxid. Med. Cell. Longev. 2017, 2017, 8370593. [CrossRef]

104. Tu, W.; Wang, H.; Li, S.; Liu, Q.; Sha, H. The Anti-Inflammatory and Anti-Oxidant Mechanisms of the Keap1/Nrf2/ARE Signaling Pathway in Chronic Diseases. Aging Dis. 2019, 10, 637-651. [CrossRef]

105. Ramírez, E.; Klett-Mingo, M.; Ares-Carrasco, S.; Picatoste, B.; Ferrarini, A.; Rupérez, F.J.; Caro-Vadillo, A.; Barbas, C.; Egido, J.; Tuñón, J.; et al. Eplerenone attenuated cardiac steatosis, apoptosis and diastolic dysfunction in experimental type-II diabetes. Cardiovasc. Diabetol. 2013, 12, 172. [CrossRef] [PubMed]

106. Travers, J.G.; Kamal, F.A.; Robbins, J.; Yutzey, K.E.; Blaxall, B.C. Cardiac Fibrosis: The Fibroblast Awakens. Circ. Res. 2016, 118, 1021-1040. [CrossRef]

107. Oeckinghaus, A.; Ghosh, S. The NF-kB family of transcription factors and its regulation. Cold Spring Harb. Perspect. Biol. 2009, 1, a000034. [CrossRef] [PubMed]

108. Rose, B.A.; Force, T.; Wang, Y. Mitogen-Activated Protein Kinase Signaling in the Heart: Angels Versus Demons in a HeartBreaking Tale. Physiol. Rev. 2010, 90, 1507-1546. [CrossRef] [PubMed]

109. Ogier, J.M.; Nayagam, B.A.; Lockhart, P.J. ASK1 inhibition: A therapeutic strategy with multi-system benefits. J. Mol. Med. 2020, 98, 335-348. [CrossRef] [PubMed] 
110. Liu, J.; Tang, Y.; Feng, Z.; Long, J. (-)-Epigallocatechin-3-gallate attenuated myocardial mitochondrial dysfunction and autophagy in diabetic Goto-Kakizaki rats. Free Radic. Res. 2014, 48, 898-906. [CrossRef] [PubMed]

111. Rieg, T.; Vallon, V. Development of SGLT1 and SGLT2 inhibitors. Diabetologia 2018, 61, 2079-2086. [CrossRef]

112. González Arbeláez, L.F.; Ciocci Pardo, A.; Fantinelli, J.C.; Caldiz, C.; Ríos, J.L.; Schinella, G.R.; Mosca, S.M. Ex Vivo Treatment with a Polyphenol-Enriched Cocoa Extract Ameliorates Myocardial Infarct and Postischemic Mitochondrial Injury in Nor-motensive and Hypertensive Rats. J. Agric. Food 2016, 64, 5180-5187. [CrossRef]

113. Dikalov, S.I.; Mayorov, V.I.; Panov, A.V. Physiological Levels of Nitric Oxide Diminish Mitochondrial Superoxide. Potential Role of Mitochondrial Dinitrosyl Iron Complexes and Nitrosothiols. Front. Physiol. 2017, 8, 907. [CrossRef] [PubMed]

114. Tan, C.; Wang, A.; Liu, C.; Li, Y.; Shi, Y.; Zhou, M.-S. Puerarin Improves Vascular Insulin Resistance and Cardiovascular Remodeling in Salt-Sensitive Hypertension. Am. J. Chin. Med. 2017, 45, 1169-1184. [CrossRef]

115. Yin, M.-S.; Zhang, Y.-C.; Xu, S.-H.; Liu, J.-J.; Sun, X.-H.; Liang, C.; Wang, Y.; Li, J.; Wang, F.-W.; Wang, Q.-L.; et al. Puerarin prevents diabetic cardiomyopathy in vivo and in vitro by inhibition of inflammation. J. Asian Nat. Prod. Res. 2019, 21, 476-493. [CrossRef] [PubMed]

116. Gertz, M.; Nguyen, G.T.T.; Fischer, F.; Suenkel, B.; Schlicker, C.; Franzel, B.; Tomaschewski, J.; Aladini, F.; Becker, C.; Wolters, D.; et al. A molecular mechanism for direct sirtuin activation by resveratrol. PLoS ONE 2012, 7, e49761. [CrossRef]

117. Rasbach, K.A.; Schnellmann, R.G. Isoflavones Promote Mitochondrial Biogenesis. J. Pharmacol. Exp. Ther. 2008, 325, 536-543. [CrossRef] [PubMed]

118. Park, J.H.; Ku, H.J.; Kim, J.K.; Park, J.W.; Lee, J.H. Amelioration of High Fructose-Induced Cardiac Hypertrophy by Nar-ingin. Sci. Rep. 2018, 8, 9464. [CrossRef] [PubMed]

119. Gandhi, G.R.; Vasconcelos, A.B.S.; Wu, D.T.; Li, H.B.; Antony, P.J.; Li, H.; Geng, F.; Gurgel, R.Q.; Narain, N.; Gan, R.Y. Citrus flavonoids as promising phytochemicals targeting diabetes and related complications: A systematic review of in vitro and in vivo studies. Nutrients 2020, 12, 2097. [CrossRef] [PubMed]

120. Carresi, C.; Musolino, V.; Gliozzi, M.; Maiuolo, J.; Mollace, R.; Nucera, S.; Maretta, A.; Sergi, D.; Muscoli, S.; Gratteri, S.; et al. Antioxidant effect of bergamot polyphenolic fraction counteracts doxorubicin-induced cardiomyopathy: Role of autophagy and c-kitposCD45negCD31neg cardiac stem cell activation. J. Mol. Cell. Cardiol. 2018, 119, 10-18. [CrossRef]

121. Roohbakhsh, A.; Parhiz, H.; Soltani, F.; Rezaee, R.; Iranshahi, M. Molecular mechanisms behind the biological effects of hes-peridin and hesperetin for the prevention of cancer and cardiovascular diseases. Life Sci. 2015, 124, 64-74. [CrossRef] [PubMed]

122. Yang, Z.; Liu, Y.; Deng, W.; Dai, J.; Li, F.; Yuan, Y.; Wu, Q.; Zhou, H.; Bian, Z.; Tang, Q. Hesperetin attenuates mitochon-driadependent apoptosis in lipopolysaccharide-induced H9C2 cardiomyocytes. Mol. Med. Rep. 2014, 9, 1941-1946. [CrossRef]

123. Yusof, N.L.M.; Zainalabidin, S.; Fauzi, N.M.; Budin, S.B. Hibiscus sabdariffa(roselle) polyphenol-rich extract averts cardiac functional and structural abnormalities in type 1 diabetic rats. Appl. Physiol. Nutr. Metab. 2018, 43, 1224-1232. [CrossRef] [PubMed]

124. Yusof, N.L.M.; Affendi, T.N.T.T.; Jubaidi, F.F.; Zainalabidin, S.; Budin, S.B. Hibiscus sabdariffa Linn. (Roselle) Polyphenols-Rich Extract Prevents Hyperglycemia-Induced Cardiac Oxidative Stress and Mitochondrial Damage in Diabetic Rats. Sains Malays. 2020, 49, 2499-2506. [CrossRef]

125. Yusof, N.M.; Zainalabidin, S.; Fauzi, N.M.; Budin, S. Cardioprotective Effects of Roselle (Hibiscus Sabdariffa Linn.) PolyphenolRich Extract in Streptozotocin-Induced Diabetic Rats. Int. J. Cardiol. 2017, 249, S4. [CrossRef]

126. Lim, Y.-C.; Budin, S.B.; Othman, F.; Latip, J.; Zainalabidin, S. Roselle Polyphenols Exert Potent Negative Inotropic Effects via Modulation of Intracellular Calcium Regulatory Channels in Isolated Rat Heart. Cardiovasc. Toxicol. 2016, 17, 251-259. [CrossRef] [PubMed]

127. Curtis, P.J.; Van Der Velpen, V.; Berends, L.; Jennings, A.; Feelisch, M.; Umpleby, A.M.; Evans, M.; O Fernandez, B.; Meiss, M.S.; Minnion, M.; et al. Blueberries improve biomarkers of cardiometabolic function in participants with metabolic syndrome-results from a 6-month, double-blind, randomized controlled trial. Am. J. Clin. Nutr. 2019, 109, 1535-1545. [CrossRef] [PubMed]

128. Sánchez Macarro, M.; Martínez Rodríguez, J.P.; Bernal Morell, E.; Pérez-Piñero, S.; Victoria-Montesinos, D.; García-Muñoz, A.M.; Cánovas García, F.; Castillo Sánchez, J.; López-Román, F.J. Effect of a Combination of Citrus Flavones and Flavanones and Olive Polyphenols for the Reduction of Cardiovascular Disease Risk: An Exploratory Randomized, Double-Blind, Place-bo-Controlled Study in Healthy Subjects. Nutrients 2020, 12, 1475. [CrossRef]

129. Curtis, P.J.; Sampson, M.; Potter, J.; Dhatariya, K.; Kroon, P.A.; Cassidy, A. Chronic Ingestion of Flavan-3-ols and Isoflavones Improves Insulin Sensitivity and Lipoprotein Status and Attenuates Estimated 10-Year CVD Risk in Medicated Postmenopausal Women with Type 2 Diabetes: A 1-year, double-blind, randomized, controlled trial. Diabetes Care 2012, 35, 226-232. [CrossRef]

130. Paul, J.; Jani, R.; Davoren, P.; Knight-Agarwal, C. Association Between a Low Carbohydrate Diet, Quality of Life, and Gly-cemic Control in Australian Adults Living with Type 1 Diabetes: Protocol for a Mixed Methods Pilot Study. JMIR Res. Protoc. 2021, 10 , e25085. [CrossRef] [PubMed]

131. Ribeiro, C.B.; Ramos, F.M.; Manthey, J.A.; Cesar, T.B. Effectiveness of Eriomin ${ }^{\circledR}$ in managing hyperglycemia and reversal of prediabetes condition: A double-blind, randomized, controlled study. Phytotherapy Res. 2019, 33, 1921-1933. [CrossRef]

132. Capomolla, A.S.; Janda, E.; Paone, S.; Parafati, M.; Sawicki, T.; Mollace, R.; Ragusa, S.; Mollace, V. Atherogenic Index Reduc-tion and Weight Loss in Metabolic Syndrome Patients Treated with A Novel Pectin-Enriched Formulation of Bergamot Poly-phenols. Nutrients 2019, 11, 1271. [CrossRef] [PubMed] 
133. Mollace, V.; Scicchitano, M.; Paone, S.; Casale, F.; Calandruccio, C.; Gliozzi, M.; Musolino, V.; Carresi, C.; Maiuolo, J.; Nucera, S.; et al. Hypoglycemic and Hypolipemic Effects of a New Lecithin Formulation of Bergamot Polyphenolic Fraction: A Double Blind, Randomized, Placebo- Controlled Study. Endocrine Metab. Immune Disord. Drug Targets 2019, 19, 136-143. [CrossRef] [PubMed]

134. Ebrahimpour-Koujan, S.; Gargari, B.P.; Mobasseri, M.; Valizadeh, H.; Asghari-Jafarabadi, M. Lower glycemic indices and lipid profile among type 2 diabetes mellitus patients who received novel dose of Silybum marianum (L.) Gaertn. (silymarin) extract supplement: A Triple-blinded randomized controlled clinical trial. Phytomedicine 2018, 44, 39-44. [CrossRef]

135. Yang, L.; Ling, W.; Yang, Y.; Chen, Y.; Tian, Z.; Du, Z.; Chen, J.; Xie, Y.; Liu, Z.; Yang, L. Role of Purified Anthocyanins in Improving Cardiometabolic Risk Factors in Chinese Men and Women with Prediabetes or Early Untreated Diabetes-A Ran-domized Controlled Trial. Nutrients 2017, 9, 1104. [CrossRef] [PubMed]

136. Shoji, T.; Yamada, M.; Miura, T.; Nagashima, K.; Ogura, K.; Inagaki, N.; Maeda-Yamamoto, M. Chronic administration of apple polyphenols ameliorates hyperglycaemia in high-normal and borderline subjects: A randomised, placebo-controlled trial. Diabetes Res. Clin. Pr. 2017, 129, 43-51. [CrossRef] [PubMed]

137. Gutiérrez-Salmeán, G.; Meaney, E.; Lanaspa, M.A.; Cicerchi, C.; Johnson, R.J.; Dugar, S.; Taub, P.; Ramírez-Sánchez, I.; Villarreal, F.; Schreiner, G.; et al. A randomized, placebo-controlled, double-blind study on the effects of (-)-epicatechin on the triglyceride/HDLc ratio and cardiometabolic profile of subjects with hypertriglyceridemia: Unique in vitro effects. Int. J. Cardiol. 2016, 223, 500-506. [CrossRef] [PubMed]

138. Kayacan, S.; Yilancioglu, K.; Akdemir, A.S.; Kaya-Dagistanli, F.; Melikoglu, G.; Ozturk, M. Synergistic Effect of Apigenin and Curcumin on Apoptosis, Paraptosis and Autophagy-related Cell Death in HeLa Cells. Anticancer. Res. 2021, 41, 1271-1282. [CrossRef] [PubMed]

139. Harasstani, O.A.; Moin, S.; Tham, C.L.; Liew, C.Y.; Ismail, N.; Rajajendram, R.; Harith, H.H.; Zakaria, Z.A.; Mohamad, A.S.; Sulaiman, M.R.; et al. Flavonoid combinations cause synergistic inhibition of proinflammatory mediator secretion from lipopolysaccharide-induced RAW 264.7 cells. Inflamm. Res. 2010, 59, 711-721. [CrossRef] [PubMed]

140. Morris, M.E.; Zhang, S. Flavonoid-drug interactions: Effects of flavonoids on ABC transporters. Life Sci. 2006, 78, 2116-2130. [CrossRef] [PubMed] 